\title{
BUSINESS ENVIRONMENT, EXPORTS, OWNERSHIP, AND FIRM PERFORMANCE
}

\author{
Simon Commander and Jan Svejnar*
}

\begin{abstract}
We use two large samples of firms to assess the effects of business environment constraints, competition, export orientation, and ownership on firm performance. We deal with omitted variables, errors in variables, and endogeneity, and find that few business constraints affect performance. Replicating the analysis with Doing Business and Heritage Foundation indicators of the business environment yields similar results. In fact, country fixed effects, reflecting time-invariant differences in the business environment as well as other factors such as health care and education, matter more for firm performance than differences in the business environment across firms within countries.
\end{abstract}

\section{Introduction}

$\mathrm{T}$ HE efficiency of firms in developing countries, including the transition economies, is obviously central to explaining the performance of these economies as a whole. In many developing countries, numerous large firms were historically state owned and widely regarded as inefficient. Indeed, almost all firms in the transition economies started as being state owned, with their objectives set consistent with the dictates of central planning. To escape these limitations, a combination of privatization, entry of new private firms, and fundamental changes in the legal, institutional, and regulatory systems has been at the core of the development and transition process over the past two decades.

The above policies have been based on the premise that a key determinant of firm performance in developing as well as developed economies is the state of the business environment, defined broadly to include the key features of the legal, regulatory, financial, and institutional systems. ${ }^{1}$ Indeed, it has been noted that the barriers to doing business vary widely across regions and countries, ${ }^{2}$ and it has been argued that the business environment will affect aggregate performance, as well as exert influence on the operation of financial markets. ${ }^{3}$ A sizable empirical literature supporting various aspects of this view has appeared, using data at the country, industry, and firm levels. However, the measurement of the business environment has encountered major methodological challenges that may have generated biased

Received for publication August 12, 2008. Revision accepted for publication May 4, 2009.

* Commander: EBRD, IE Business School, IZA; Svejnar: University of Michigan, CERGE-EI, CEPR, IZA.

We thank Hein Bogaard, Randolph Bruno, and Matias Busso for excellent assistance in preparing this article. We thank John DiNardo, Sam Fankhauser, Steven Fries, Yuriy Gorodnichenko, Alex Muravyev, Mark Schaffer, Katrin Tinn, and Utku Teksoz for helpful discussion and/or comments on an earlier version. The paper was written with the support of EBRD. Jan Svejnar also benefited from the Grant Agency of the Czech Republic (Grant P402/10/2130). The usual disclaimer applies.

${ }^{1}$ See, for example, World Bank (2002) and EBRD (1999).

2 World Bank (2005); World Economic Forum (2005).

${ }^{3}$ See Hausmann, Rodrik, and Velasco (2004). For the financial market angle, see Durnev et al. (2004). estimates on account of issues such as errors in variables, omitted variables, and endogeneity of regressors.

First, much of the knowledge in this area derives from studies that rely on country-level proxy indicators of the business environment, such as governance (Kaufmann, 2002; Kaufmann, Kraay, \& Zoido-Lobaton, 1999) regulatory constraints (Djankov \& Murrell, 2002; Botero et al., 2004); competitiveness (World Economic Forum); transparency (Transparency International); bureaucratic quality, corruption, and law and order (Political Risk Services); strength of the legal system (Durnev \& Kim, 2005); and the level of economic freedom in an economy (Heritage Foundation). Many of these aggregate proxies of the actual phenomena contain little or no variation over time and thus are completely or almost indistinguishable from country-, sector-, or region-specific effects that may reflect many other features than the business environment. Second, the aggregate studies usually estimate the association between features of business environment and macroeconomic performance rather than identify the causal effects of the environment on performance (see, for example, the discussion in Levine \& Zervos, 1998, and Rajan \& Zingales, 1998).

Industry-level studies, such as Rajan and Zingales (1998), Klapper and Love (2004), and Micco and Pages (2006), estimate the effects of a particular feature of the business environment on industry performance. They represent an advance over country-level studies in that they can control for country and industry effects and thus suffer less from an omitted variable bias. The trade-off is that in order to identify the performance effect with industry-level data, these studies assume that one country, the United States, has an optimal value of the particular feature of business environment and that there is some technological or other reason that in all countries, some industries depend more than others on this feature of the environment. While these studies attempt to account for the possible endogeneity of the business environment, the extent of their ability to tackle this issue is naturally limited.

Finally, a number of firm-level studies have been carried out in the past few years, taking advantage of cross-firm variation in performance and in perceived or actual severity of business environment constraints. While these studies represent an important advance over the ones based on more aggregate data, they also suffer from a number of the aforementioned econometric problems. For example, using a 1995 survey of about 440 firms in Bulgaria and Russia, Pissarides, Singer, and Srejnar (2003) examine the absolute and relative severity of various constraints and how it relates to the characteristics of the manager, firm, and sector of operation, but they do not address the issue of 
endogeneity of regressors. Johnson, McMillan, and Woodruff (2002a, 2002b) use a 1997 firm-level survey of about 1,400 firms in five transition economies to estimate the effects of property rights and access to credit on profit reinvestment, but also assume that all regressors are exogenous. Dollar, Hallward-Driemeier, and Mengistae (2005) use surveys from eight developing countries covering nearly 6,500 firms to look at the association between exporting and the investment climate. The empirical implementation relies, however, on probit estimations where perceived constraints are entered on the right hand side and assumed to be exogenous. Beck, Demirguc, and Maksimovic (2005) use the World Business Environment Survey (WBES) of more than 4,000 firms in 54 countries to examine the effect of business environment constraints on firm growth, but do not address endogeneity, and in most estimations they enter the constraints one at a time rather than simultaneously. They also do not control for country and industry heterogeneity with country and industry fixed effects, relying instead on country random effects and a manufacturing and a services dummy variable. Hallward-Driemeier, Wallstein, and $\mathrm{Xu}$ (2006) use an investment climate survey administered in 2000 to 1,500 Chinese firms in five cities, with some constraints being measured by managerial perceptions and others by management-provided information on phenomena such as losses in sales due to power problems. The authors are concerned with endogeneity, find the instrumental variable approach infeasible, and use city-industry average values of the business climate variables, together with city information and sector dummies, to alleviate the endogeneity problem. They address the omitted variable problem by entering all the constraint variables simultaneously, but firm ownership is treated as exogenous. Finally, Ayyagari and Demirguc-Kunt (2008) examine the importance of financing (but not other) constraints in explaining firm performance using the cross-sectional WBES data for eighty countries, relating firm growth rates to the different obstacles that the firms report. They strive to control for endogeneity and, like this study, use information about perceived constraints by other firms in the same industry and country as instrumental variables for the perceived constraints in the own firm. In short, although the literature is rich and informative, the conclusions that can be drawn are still quite tentative because of the estimation issues discussed. ${ }^{4}$

In parallel to the investigations of the effects of business environment, researchers have been analyzing the effects on firm performance of three key structural features: the extent of the firm's export orientation, competition, and ownership. The number of studies and findings is large, but

\footnotetext{
${ }^{4}$ There are also other conceptual issues, noted for instance by Carlin, Schaffer, and Seabright (2006), who argue that subjective evaluations of constraints can provide important insights but need to be carefully interpreted. For example, reported constraints for public goods, as against those relating to finance, may require different interpretation, as the former may act as a common constraint on firms in a country, while the latter may vary between firms, let alone between countries.
}

the overall sense is that the performance effects of exports are found to be positive (see Tybout, 2003, for a review); those of competition are found to be positive by Nickell (1999), but questioned as a uniform effect by Carlin et al. (2004) and Aghion et al. (2005); and the effect of ownership is found to be generally positive for foreign ownership but less clear-cut for domestic private ownership (Estrin et al., 2009). ${ }^{5}$ Interestingly, while this work often uses the same or similar dependent variables; each of them focuses on a particular set of explanatory variables and usually does not take into account the explanatory variables deemed important in other strands of research. This raises the issue of whether existing studies generate biased estimates on account of omitted variables.

In this paper, we carry out an econometric analysis of a large firm-level survey data set that includes measures of performance, structural variables related to ownership, competition and export orientation, and each firm's top manager's perception of the business environment that his or her firm faces. Specifically, we use the 2005 and 2002 Business Environment and Enterprise Performance Survey (BEEPS), collected by the European Bank for Reconstruction and Development (EBRD) and the World Bank, to examine what robust relationships, if any, can be identified by linking firm performance in 26 transition countries to a range of explanatory variables, including the firm's business environment, ownership, export orientation, and competition. Aside from providing a large number of observations, over 4,000 firms in 2002 and 6,600 firms in 2005, the BEEPS data set also provides data on firms over a six-year period, as it includes three-year retrospective information for each survey round. Our objective is to assess whether the widely accepted claim that the business environment and structural features of firms are major explanatory factors behind performance is supported in our large data set under a series of econometric tests. Earlier research that looked into the determinants of firm performance in the transition countries has found that privately owned firms, especially new private firms, have generally performed better. The evidence also points to foreign participation and exposure to export markets as factors associated with strong performance, whether measured in terms of sales, labor productivity, or total factor productivity (output relative to labor and capital inputs). ${ }^{6}$ However, ownership change does not appear to have had any positive impact on performance without complementary changes in management structure, financing, the competitive environment, or other factors specific to the firm. Further, some recent evidence has suggested that privatized domestic firms do not necessarily perform markedly better than the remaining state-owned firms.

\footnotetext{
${ }^{5}$ Surveys by Djankov and Murrell (2002) and Estrin et al. (2009) point to the positive effect of foreign ownership. While Djankov and Murrell also find a positive effect of domestic private ownership, Estrin et al. find this effect to be much weaker and more varied.

${ }^{6}$ See, for example, Carlin (2000), Claessens and Djankov (1999), Frydman et al. (1999), and EBRD (1995, 1999).
} 
Moreover, the evidence suggests that all types of domestic firms in transition countries continue to lag behind their equivalents in advanced market economies. ${ }^{7}$ Domestic firms tend to have lower efficiency in generating output from inputs, while their scope for raising prices may be limited by product quality, poor marketing, and highly competitive markets. In addition, they tend to have fewer intangible assets, greater vertical integration, and higher financing costs. Research on the determinants of firm performance has also begun to look at how factors external to the firm can also exert an influence on performance. Studies using earlier rounds of the BEEPS have suggested that a better business environment can indeed have a positive effect on performance, although the size - and robustness - of that effect have remained open to question. ${ }^{8}$

Our paper extends this literature by relating firm performance not only to a set of ownership variables but also to other key attributes, including perceived constraints, competition, and export orientation. Further, we pay particular attention to the likely problems of endogeneity by adopting a number of approaches, including instrumental variables (IVs) and the use of average values of constraints for other similar firms, and by assessing the seriousness of the omitted variable bias. We focus on how efficiently firms generate sales revenue, taking into account capital, labor, and industry-level price. This is equivalent to total factor productivity but broader in that it also captures improvements in pricing within industry, marketing, and other aspects of revenue generation. Our approach is similar to other productivity analyses using firm-level data since very few have firm-level prices. We accordingly emphasize the importance of this measure because the performance of different types of firms may vary for a number of reasons, including differences in efficiencies in generating output from inputs, but also differences in the ability to charge high prices due to diverse product quality or marketing, intangible assets and the cost of capital, location in highly competitive industries, efficiency of vertical integration, and the extent of outsourcing. In order to capture as many of these factors as possible, we focus on the revenues of the firm as our dependent variable. Our approach explicitly allows the efficiency of different firms to vary on account of any of these factors. We do not presume that firms are in a technical or economic steady state but rather that they are trying to improve their performance by discovering new methods of production, importing advanced technologies, launching new products, learning new managerial and marketing techniques, and implementing other changes. The extent to which firms are able to succeed may, of course, also depend on the macroeconomic, legal, and institutional environment. The paper focuses on this association —or its absence.

\footnotetext{
${ }^{7}$ See, for example, Sabirianova, Svejnar, \& Terrell (2005b) and Hanousek, Kocenda, and Svejnar (2007).

${ }^{8}$ See Carlin et al. (2001).
}

We find that foreign (but not domestic private) ownership and competition have an impact on performance, measured as the level of sales controlling for inputs. Export orientation of the firm does not have an effect on performance once ownership is taken into account. When we analyze the impact of perceived constraints, we show that few retain explanatory power once they are introduced jointly rather than one at a time, or when country and year fixed effects are introduced. Indeed, country fixed effects largely absorb the explanatory power of the constraints that individual firms face. Replicating the analysis with commonly used country-level indicators of the business environment (Heritage Foundation indices and World Bank's Doing Business indicators), as well as a different firm-level data set (AMADEUS), we do not find much of a relationship between constraints and performance. Given that much donor funding has been conditioned on improvements in business environment, the question arises as to whether other development policies that use bilateral or multilateral funding yield similarly insignificant effects. We take a step toward answering this question by exploring whether indicators such as countrywide tertiary school enrollment or per capita expenditures on health care have a significant effect on firm performance relative to the business environment constraints. We find that health care expenditure per GDP has a strong, positive effect on firm performance relative to the BEEPS and Doing Business indicators of business environment, but that its effect is less significant when estimated jointly with the Heritage Foundation indicators. Including GDP per capita has a positive effect on performance and suggests that the country fixed effects that eliminate the effect of the individual business constraints are well approximated by intercountry differences in GDP per capita. Our analysis brings into question an important part of the conventional wisdom in this area. It indicates that country fixed effects, reflecting time-invariant differences in the business environment but also many other factors, matter for firm performance, but that differences in the business environment observed by top managers do not. This suggests that the analyst's ability to identify the effects of business environment on firm performance, and possibly the effects themselves, have been more limited than has been widely assumed.

The paper is organized as follows. In section II, we describe the data, while in section III, we outline the analytical framework. We present our empirical findings in section IV. Given our findings, section V then explores further what factors appear to affect firm performance. Section VI concludes.

\section{Data Description}

We base most of our analysis on the 2002 and 2005 rounds of the BEEPS. ${ }^{9}$ The BEEPS data are stratified ran-

\footnotetext{
${ }^{9}$ The BEEPS rounds for 2002 and 2005-including questionnaires, information on sampling methodology and complete responses-are available online at http://www.ebrd.com/economics.
} 
Table 1.-Descriptive Statistics

\begin{tabular}{|c|c|c|c|c|c|c|}
\hline & \multicolumn{3}{|c|}{2002} & \multicolumn{3}{|c|}{2005} \\
\hline & Observation & Mean & S.D. & Observation & Mean & S.D. \\
\hline \multicolumn{7}{|l|}{ A: Summary Statistics } \\
\hline Sales & 4,504 & 2,290 & 10,428 & 6,665 & 3,376 & 17,503 \\
\hline Employment & 6,122 & 143 & 505 & 9,097 & 105 & 364 \\
\hline Fixed assets & 3,388 & 2,384 & 33,893 & 4,637 & 1,622 & 10,582 \\
\hline Number of competitors & 6,029 & 0.82 & 0.39 & 8,479 & 0.82 & 0.39 \\
\hline Ownership (privatization) & 6,153 & 0.15 & 0.36 & 9,098 & 0.14 & 0.35 \\
\hline Ownership (new private) & 6,153 & 0.55 & 0.550 & 9,098 & 0.66 & 0.47 \\
\hline Ownerschip (state) & 6,153 & 0.14 & 0.35 & 9,098 & 0.09 & 0.28 \\
\hline Ownership (other) & 6,153 & 0.02 & 0.12 & 9,098 & 0.01 & 0.09 \\
\hline Ownership (foreign) & 6,153 & 0.14 & 0.35 & 9,098 & 0.10 & 0.30 \\
\hline Exports as $\%$ of sales & 6,055 & 11.16 & 25.05 & 9,039 & 8.76 & 22.34 \\
\hline Workforce ratio: University/secondary education & 5,289 & 1.36 & 4.67 & 6,930 & 1.24 & 3.83 \\
\hline Company age & 6,153 & 14.70 & 18.70 & 9,090 & 15.55 & 17.46 \\
\hline University/secondary education $\times$ Age & 5,289 & 19.47 & 114.49 & 6,925 & 22.84 & 124.76 \\
\hline Permanent employment 3 years ago & 6,066 & 134.73 & 501.85 & 8,967 & 101.51 & 405.07 \\
\hline Part-time employment 3 years ago & 5,872 & 6.96 & 44.21 & 8,873 & 5.65 & 31.70 \\
\hline$\%$ change in fixed assets (3-year period) & 5,717 & 16.30 & 46.66 & 8,787 & 11.90 & 32.17 \\
\hline$\%$ change in exports (3-year period) & 6,026 & 5.44 & 33.76 & 9,030 & 4.44 & 29.81 \\
\hline$\%$ change in employment ( 3 -year period) & 6,059 & 34.89 & 135.99 & 8,967 & 30.30 & 133.53 \\
\hline$\%$ change in sales (3-year period) & 5,832 & 21.69 & 62.74 & 8,764 & 12.99 & 39.25 \\
\hline$\%$ change in sales per worker (3-year period) & 5,753 & 14.69 & 74.90 & 8,645 & 12.35 & 89.17 \\
\hline \multicolumn{7}{|l|}{ B: Average Number of Competitors } \\
\hline Construction & 772 & 2.85 & 0.39 & 443 & 2.86 & 0.41 \\
\hline Manufacturing & 1,463 & 2.72 & 0.49 & 2,161 & 2.75 & 0.49 \\
\hline Transport, storage, and communications & 474 & 2.72 & 0.52 & 339 & 2.79 & 0.47 \\
\hline Wholesale and retail trade & 1,847 & 2.88 & 0.34 & 949 & 2.84 & 0.40 \\
\hline Real estate renting and business services & 637 & 2.82 & 0.41 & 396 & 2.82 & 0.45 \\
\hline Other services & 768 & 2.81 & 0.43 & 317 & 2.74 & 0.53 \\
\hline Others & 68 & 2.53 & 0.63 & 60 & 2.53 & 0.68 \\
\hline \multicolumn{7}{|l|}{ C: Average Constraints } \\
\hline Access to financing & 5,810 & 2.33 & 1.16 & 8,647 & 2.26 & 1.14 \\
\hline Cost of financing & 5,864 & 2.53 & 1.13 & 8,698 & 2.51 & 1.13 \\
\hline Tax rates & 6,060 & 2.76 & 1.11 & 8,951 & 2.75 & 1.10 \\
\hline Tax administration & 5,953 & 2.54 & 1.14 & 8,895 & 2.47 & 1.13 \\
\hline Custom/foreign trade regulations & 5,649 & 2.04 & 1.12 & 8,267 & 1.91 & 1.07 \\
\hline Business licensing and permit & 5,906 & 2.02 & 1.08 & 8,776 & 1.98 & 1.04 \\
\hline Labour regulations & 5,946 & 1.74 & 0.94 & 8,886 & 1.87 & 0.98 \\
\hline Uncertainty about regulatory policies & 6,000 & 2.85 & 1.09 & 8,819 & 2.53 & 1.12 \\
\hline Macroeconomic instability & 5,998 & 2.76 & 1.11 & 8,823 & 2.52 & 1.12 \\
\hline Functioning of the judiciary & 5,728 & 2.06 & 1.08 & 8,417 & 2.06 & 1.10 \\
\hline Corruption & 5,713 & 2.24 & 1.16 & 8,497 & 2.16 & 1.14 \\
\hline Street crime theft and disorder & 5,857 & 1.96 & 1.07 & 8,661 & 1.82 & 1.01 \\
\hline Organized crime & 5,663 & 1.81 & 1.09 & 8,394 & 1.64 & 0.97 \\
\hline Anticompetitive practices & 5,871 & 2.25 & 1.11 & 8,739 & 2.30 & 1.11 \\
\hline Infrastructure & 6,122 & 1.54 & 0.70 & 9,043 & 1.54 & 0.73 \\
\hline Average of all constraints & 6,134 & 2.24 & 0.67 & 9,064 & 2.17 & 0.66 \\
\hline
\end{tabular}

dom samples of firms. Concerning ownership, most firms in the samples were privatized or had always been private from the start of their operations. However, quota sampling was imposed for foreign-owned companies (defined as having a foreign stake of at least 50\%) and state-owned companies (defined as the state owning more than 50\%). These quotas were set at $10 \%$ of the total sample for each category. The distribution of the sample between manufacturing and service sectors was determined according to these sectors' relative contribution to GDP in each country. Firms that operated in sectors subject to government price regulation and prudential supervision, such as banking, electric power, rail transport, and water, were excluded from the sample. ${ }^{10}$ Firms that had 10,000 employees or more were excluded from the sample, as were firms that had started operations in 2002, 2003, or 2004. Around 90\% of the BEEPS sample in both years were small and medium enterprises. The 2002 round of the BEEPS surveyed over 6,100 firms from 26 transition countries, while the 2005 round covered nearly 9,100 firms in the same countries. The summary statistics on the number of observations, means, and standard deviations of the key variables are given in table 1

\footnotetext{
${ }^{10}$ In the 2005 round, of the eligible firms that were approached the refusal rate was around $48 \%$.
} 
for the 2002 and 2005 data sets. Values are expressed in U.S. dollars.

As can be seen from table 1, the key variables display reasonable mean values and significant variation. Panel A indicates that the average age of the firm was around fifteen years. The average firm had between 105 and 145 employees in both surveys. Employment, fixed assets, sales, and sales per worker all increased between 1999 and 2002, as well as between 2002 and 2005. In the case of employment, growth over these three-year periods was greater than $30 \%$, while for sales, growth actually decelerated after 2002. The increase in sales per worker was roughly equal over both three-year periods. The variation in employment, sales, and capital across firms and in their growth has been substantial, as indicated by the standard deviations. Exports have constituted about $10 \%$ of sales, and there has again been considerable variation around the mean in both years. In terms of ownership-related performance statistics not reported in table 1, foreign firms have had about $40 \%$ higher levels of sales per worker than state-owned firms. Privatized state firms have had around $10 \%$ higher levels, while new private firms have been about $20 \%$ higher. Overall, the average foreign firm has produced $20 \%$ to $50 \%$ more sales revenue and has had $20 \%$ to $40 \%$ higher revenue per worker than the average domestic firm. However, the difference between foreign and domestic firms could be due, in part or fully, to foreign owners acquiring better-performing firms. ${ }^{11}$

Panel B of table 1 provides descriptive information concerning competition, specifically the average number of competitors in the domestic market reported by firms in both 2002 and 2005, disaggregated by sector. What emerges is that there is little perceived difference across regions or sectors, as well as little change over the two periods. The average number of perceived competitors falls between 2.5 and 3.0 in each sector, but there is considerable variation within each sector and this variation has risen over time.

Panel C of table 1 gives for 2002 and 2005 the mean constraint scores and the associated standard deviations for the fifteen main constraints that the top manager of each firm was asked to evaluate. Individual firm scores for each constraint to doing business range from 1 (no obstacle) to 4 (a major obstacle). The panel shows considerable variation in the average value across constraints, ranging from 1.54 in both years for the presence of anticompetitive practices to 2.85 in 2002 for uncertainty about regulatory policies and 2.75 in 2005 for the constraining nature of tax rates. There is also considerable variation in the reported values of individual constraints across firms, with the standard deviation of the responses being around or exceeding 1.0 for all but one constraint (infrastructure) in each year. Averaging the reported values of all fifteen constraints, the mean score in both years was 2.2, with a standard deviation of around 0.7. Further, the variation is considerable when we look for each

\footnotetext{
${ }^{11}$ This finding is corroborated by other studies of individual or smaller sets of countries (see, for example, Sabirianova et al., 2005b).
}

country and year at the average value of the reported constraint at the level of four-digit NACE industry and across firm size.

As we discuss later, we have also been able to construct a panel component of approximately 1,300 firms that participated in both the 2002 and 2005 rounds of the BEEPS. While relatively small, this panel data set is useful for a complementary analysis to the pooled cross-sectional data set. $^{12}$

\section{Analytical Framework}

In analyzing the determinants of the efficiency with which the firms generate sales revenue from inputs, we use an augmented Cobb-Douglas function,

$\ln y_{i t}=\beta_{0}+\Sigma_{k} \beta_{k} \ln x_{i k t}+\rho Z_{i t}+\delta I_{i t}+\theta C+\varsigma T_{t}+v_{i}+\varepsilon_{i t}$,

where $y_{i t}$ represents the revenue of firm $i$ in period $t ; x$ 's represent the capital and labor inputs; $Z_{i t}$ is a vector of the business environment and structural variables (business constraints, export orientation of the firm, extent of product market competition, and firm ownership); the I's, C's, and $T$ 's denote a set of dummy variables for industries, countries, and years, respectively; $v_{i}$ is an unobserved timeinvariant firm-specific effect that we control for in some estimations; and $\varepsilon_{i t}$ is an independently distributed error term. Equation (1) allows efficiency to vary across institutional and structural variables, industries, countries, and time.

Equation (1) represents our basic specification. We also have access to a measure of material inputs, but this has fewer observations and is noisier than the measures of labor and capital. However, to check the robustness of our results, we also estimate equation (1) with the log of value added as the left-hand-side variable (value added being defined as the difference between revenues and the material input variable). Moreover, as we discuss below, using the panel data, we are able to provide estimates of an initial value equation in which we regress the rate of change of revenues between 2002 and 2005 on the 2002-2005 rate of change of labor and capital and on the 2002 levels of the business environment constraints and the structural variables (ownership, competition, and export orientation).

In estimating equation (1), the question that naturally arises is how best to control for the potential endogeneity and selection issues related to some of the explanatory variables. In particular, given the nature of the privatization process, firm ownership may not be assigned at random, and there is generally a need to account for possible unobserved heterogeneity and to isolate the effect of inputs, per-

\footnotetext{
12 To make the matching of the panel firms between 2002 and 2005 data sets possible, the latter includes the variable seno2002, comprising the serial numbers of the participating firms from the former survey.
} 
ceived business environment, and structural factors on a firm's performance from the effects of performance on these explanatory variables. ${ }^{13}$ We use an instrumental variable (IV) approach, noting that we are fortunate that the BEEPS data contain a large number of firms because IV estimates are consistent but not unbiased. However, controlling adequately for endogeneity is not an easy task in survey data that do not come from a natural experiment. We use several complementary approaches to estimate the average effect of the explanatory variables on performance. First, for several key variables, the 2002 and 2005 samples provide information on the rate of change between 1999 and 2002 and between 2002 and 2005, so that we can use three-year lagged levels and lagged three-year differences in some of these variables as potential instrumental variables for our cross-sectional analysis of the 2002 and 2005 levels of variables. For each year in each firm, we also have data on the number of workers with university and secondary education, and, following Marschak and Andrews (1944) and Schmidt (1988), we can use the ratio of these two inputs (skill ratio) as an instrumental variable. The rationale for the skill ratio instrument comes from economic optimization and an assumed exogeneity of input prices (wages). In particular, if the production function is CobbDouglas and the firm maximizes profit or minimizes cost, the first-order conditions dictate that the ratio of inputs equals the ratio of input prices and technological parameters. If the firm is a price taker in the input markets, the ratio of inputs reflects these exogenous factors. ${ }^{14}$ The use of a skill ratio hence relies on the exogeneity of the ratio of wages of the more and less educated workers at the firm level and on variation in this wage ratio across regions, countries, and over time. Since firms in our survey operate in very different regions and countries, and returns to human capital have risen over time, the ratio of wages of workers with greater and lesser education varies considerably across our observations.

Given that the bias of two-stage least squares is proportional to the degree of overidentification, our approach has been to estimate the first-stage regressions with as few IVs as possible, while ensuring that the IVs have adequate explanatory power and pass the overidentification tests. In particular, we start by estimating equation (1) in levels on the pooled 2002 and 2005 samples of firms, and we use as IVs the age and location of the firm, the skill ratio interacted with the three main regions covered by our data, the skill ratio interacted with firm age and the three regions, a three-year lagged number of full-time employees, the percentage change in fixed assets in the preceding three years, and the percentage change in exports over the preceding

\footnotetext{
${ }^{13}$ Gupta, Ham, and Svejnar (2008), for instance, show that better-performing firms tend to be privatized first, while Sabirianova et al. (2005a) find that foreign firms acquire better-performing domestic firms.

${ }^{14}$ We use these assumptions but note that if more complicated labor market matching occurred (for instance, assortative matching of workers with firms), the assumption of exogeneity could not be maintained.
}

three years. ${ }^{15}$ We use these variables as instruments for the levels of the capital and labor inputs, four categories of ownership, and the export orientation of the firm. We find that the IVs are good predictors of all the potentially endogenous variables and pass the $J$ (Sargan) overidentification test. ${ }^{16}$ We treat the extent of competition in the firm's product market as exogenous to a given firm.

Conceptually, the IVs that we use reflect (a) the environment and background of the firm (location and age), (b) labor market and technological factors (relative wages and technology determining the skill ratio), (c) Arellano-Bond type factors (lagged percentage change in assets and exports determining the current levels of the potentially endogeneous variables), and (d) the effect of three-year lagged level of full-time employment on current levels of the potentially endogeneous variables. The credibility of our results would naturally be enhanced if similar coefficient estimates were generated with alternative choices (subsets) of instruments. In particular, the use of a lagged level of full-time employment as an IV for current levels of variables may be regarded as questionable, even with a threeyear lag, in the sense that the presence of a fixed effect could induce correlation between the IV and the error term in equation (1). We have therefore estimated a series of exactly identified models with various subsets of the IVs listed in categories a to d. From the first-stage $F$-tests we have found that most of these IVs are needed because different sets of IVs predict different endogenous variables. For instance, the location and age variables tend to be important predictors of the level of inputs and ownership, while lagged percentage changes in assets and exports are good predictors of the current export orientation of the firm. Interestingly, our results do not change due to the inclusion of the three-year lagged level of full-time employment as an instrument. The IVs we use hence have merit, but as is usual with internal IVs, there remains some question as to whether they yield unbiased estimates. As we discuss below, we perform another robustness check by reestimating equation (1) in the form of a Solow residual or total factor productivity (TFP) equation to obtain coefficient estimates on the variables of interest without the need to instrument the inputs.

In order to assess the robustness of our results with respect to the business environment (institutional) constraints, we have estimated these effects in several ways. First, we have carried out estimations using the individual values of the constraints directly as reported by the top

\footnotetext{
15 The location variable is a dummy variable coded 1.0 for cities and towns of at least 50,000 inhabitants and 0.0 otherwise. The regions are Central Europe and Baltics, the Commonwealth of Independent States (CIS), and southeastern Europe.

${ }_{16}$ The summary statistics from the first-stage estimates are reported in the tables with the second-stage results. Complete results of the first-stage regressions are available on request. Given the choice of IVs, the need to address the endogeneity issue is also indicated by the Hausman-Wu $F$ tests and Durbin-Hausman-Wu chi square tests that suggest that the null hypothesis of the exogeneity of the regressors is rejected in our data.
} 
managers of the interviewed firms. This approach has the advantage that it provides a direct firm-specific measure and generates high variance in the values of these variables, but it may produce biased estimates if a manager's perception of the severity of constraints is, for instance, influenced by the performance of his or her firm. ${ }^{17}$ Second, in order to address this potential endogeneity bias, we have carried out estimations in which we instrument the individual managers' values of constraints with the above-mentioned, as well as other, IVs. Third, we have used an average value of each constraint reported by other firms, where the average is based on responses of either all other firms in a given industry in each country and year or all other firms of a given size in a given industry in each country and year. The advantage of using the responses of other firms that are subject to the same external shocks is that the value of the constraint is not affected by the firm's own performance. It turns out that the estimates based on all the above approaches are similar, with estimates based on the average value of constraints reported by other firms of a given size in a given NACE two-digit industry in each country and year being slightly more frequently significant than others. Since our analysis suggests that the literature has overstated the significance of the effect of business constraints on firm performance, in what follows we report the set of estimates based on the average values of constraints reported each year by other firms within a given two-digit industry and firm size category (small, medium, and large) in a given country, which provide the greatest support for the existing literature and go most against our thesis. This approach gives both a considerable variation in the values of constraints and a sufficient number of firms per cell to minimize problems associated with potential measurement error. The standard errors of all reported estimates are clustered by year, country, industry, and firm size. Clustering by just year and country or using unclustered (just heteroskedasticrobust) standard errors yields similar results.

Finally, we perform another robustness check by reestimating equation (1) in the form of a Solow (TFP) residual. This amounts to subtracting from each firm's revenue its inputs weighted by industry and country-specific cost shares. We construct the cost shares from our firm-level data in the standard way done in the productivity literature: by computing for each firm the cost shares (for example, expenditure on labor in total cost) and then taking an average in a given industry and year. We then regress the Solow residual (TFP) on the explanatory variables that we useconstraints (as defined above), competition, and ownership but leaving out exports as an explanatory variable. The coefficient on exports is statistically insignificant in all the other regressions we run, and its exclusion does not materi-

\footnotetext{
${ }^{17}$ For example, managers of efficient firms operate near full capacity and feel constrained, while managers of poorly performing firms may have considerable unused capacity and do not find many constraints binding.
}

ally affect the results. This obviates the need to instrument because the inputs are now part of the dependent variable, constraints are purged of endogeneity by taking averages, competition is exogenous to a given firm, and privatization is taken as predetermined because it took place in the preceding decade and the adjustment had thus already taken place by the time of our sample period.

Our second approach is to use the (smaller) panel data set that we have constructed from the 2002 and 2005 BEEPS surveys to explain the three-year rate of change in performance. For this analysis, we have over 600 firms, and as we discuss below, the sample is relatively representative of the larger cross-section of firms. The panel data generate broadly similar estimates as the entire pooled crosssectional sample, suggesting that the panel data set is a usable subset of the entire sample. Using the panel data, we estimate an equation in which we regress the rate of change of revenues between 2002 and 2005 on the 2002-2005 rate of change of labor and capital and on the 2002 levels of the business environment constraints and structural variables. This initial value regression parallels the specification used by Levine and Zervos (1998) at the macrolevel and allows us to ask the question of how initial (2002) conditions affect the subsequent (2002-2005) rate of change of performance. $^{18}$

The principal variables whose performance effect we analyze include the intensity of the various constraints reported by the firms, firm ownership, the extent of competition faced by the firm, and the extent of exporting carried out by the firm. In addition, coefficients on country dummy variables provide an estimate of the effect on efficiency of the business environment at the country level. We also apply a sector fixed effect in the estimations reported below and, where possible, a year dummy.

\section{Effects of Ownership, Competition, Exports, and Business Environment}

\section{A. Level of Efficiency}

Table 2 contains our baseline IV estimates without the explanatory variables capturing the business environment (institutional) constraints. These regressions use pooled data from the entire 2002 and 2005 BEEPS and correspond to studies that have examined the efficiency effects of exporting, competition, and firm ownership. The number of observations varies from 5,624 to 5,897, depending on specification, and the results are therefore based on the largest data set available to us. All regressions include country, year, and sector (industry) fixed effects. State ownership serves as the reference, and the coefficients on other owner-

\footnotetext{
18 This is about as far as we can go in this type of estimation, however, since for most firms, we have data on the percentage change in revenues between 2002 and 2005, but we lack observations for the rate of change from 2002 to 2005 for many of the explanatory variables. As such, we cannot estimate equation (1) in first differences.
} 
Table 2.-Revenue Efficiency-Baseline Regressions (IV Estimation with Year, Country, and Sector Fixed Effects)

\begin{tabular}{|c|c|c|c|c|c|c|c|c|}
\hline & 1 & 2 & 3 & 4 & 5 & 6 & 7 & 8 \\
\hline \multirow[t]{2}{*}{ Log employment } & 0.189 & 0.190 & 0.203 & 0.236 & 0.449 & 0.466 & 0.508 & 0.503 \\
\hline & [0.177] & {$[0.177]$} & {$[0.177]$} & {$[0.163]$} & {$[0.184]^{* *}$} & {$[0.200]^{* *}$} & {$[0.179]^{* * *}$} & {$[0.188]^{* * *}$} \\
\hline \multirow[t]{2}{*}{ Log assets } & 0.904 & 0.880 & 0.891 & 0.826 & 0.522 & 0.498 & 0.467 & 0.470 \\
\hline & {$[0.190]^{* * *} *$} & {$[0.190]^{* * *}$} & {$[0.182]^{* * *}$} & {$[0.177]^{* * *}$} & {$[0.182]^{* * *}$} & {$[0.213]^{* *}$} & {$[0.192]^{* *}$} & {$[0.177]^{* *}$} \\
\hline \multirow{2}{*}{$\log (1+$ export/sales $)$} & & 0.743 & & 0.981 & & -0.540 & & -0.218 \\
\hline & & {$[0.359]^{* *}$} & & {$[0.392]^{* *}$} & & {$[0.493]$} & & {$[0.506]$} \\
\hline \multirow[t]{2}{*}{ More than 3 competitors } & & & 0.040 & 0.066 & & & 0.072 & 0.075 \\
\hline & & & {$[0.052]$} & {$[0.050]$} & & & {$[0.044]^{*}$} & {$[0.046]$} \\
\hline \multirow[t]{2}{*}{ Ownership (privatized) } & & & & & -0.435 & -0.205 & -0.222 & -0.159 \\
\hline & & & & & [0.428] & {$[0.423]$} & [0.384] & {$[0.405]$} \\
\hline \multirow[t]{2}{*}{ Ownership (new private) } & & & & & -0.531 & -0.523 & -0.408 & -0.424 \\
\hline & & & & & {$[0.284]^{*}$} & {$[0.283]^{*}$} & {$[0.258]$} & {$[0.263]$} \\
\hline \multirow[t]{2}{*}{ Ownership (foreign) } & & & & & 1.196 & 1.728 & 1.388 & 1.591 \\
\hline & & & & & {$[0.367]^{* * *}$} & {$[0.544] * * *$} & {$[0.350]^{* * *}$} & {$[0.520] * * *$} \\
\hline \multirow[t]{2}{*}{ Constant } & 1.352 & 1.330 & 1.291 & 1.297 & 2.285 & 2.302 & 2.135 & 2.141 \\
\hline & {$[0.251] * * *$} & {$[0.251] * * *$} & {$[0.273] * * *$} & {$[0.265] * * *$} & {$[0.417]^{* * * *}$} & {$[0.444]^{* * *}$} & {$[0.444] * * *$} & {$[0.427] * * *$} \\
\hline Observations & 5,897 & 5,844 & 5,677 & 5,624 & 5,897 & 5,844 & 5,677 & 5,624 \\
\hline$J$-test & 17.78 & 14.12 & 16.89 & 12.16 & 3.19 & 1.58 & 1.50 & 0.95 \\
\hline$p$-value & 0.003 & 0.007 & 0.005 & 0.016 & 0.203 & 0.209 & 0.472 & 0.328 \\
\hline \multicolumn{9}{|l|}{ First-stage $F$-tests } \\
\hline Log employment & 109.14 & 107.58 & 112.52 & 110.63 & 109.14 & 107.58 & 112.52 & 110.63 \\
\hline Log assets & 50.63 & 49.97 & 48.24 & 47.56 & 50.63 & 49.97 & 48.24 & 47.56 \\
\hline $\log (1+$ export/sales $)$ & & 18.05 & & 18.09 & & 18.05 & & 18.09 \\
\hline Ownership (privatized) & & & & & 22.56 & 22.17 & 22.20 & 21.82 \\
\hline Ownership (new private) & & & & & 70.74 & 71.27 & 70.98 & 71.34 \\
\hline Ownership (foreign) & & & & & 12.36 & 11.96 & 12.42 & 12.02 \\
\hline \multirow{2}{*}{$\begin{array}{l}\text { Durbin-Wu-Hausman test } \\
p \text {-value }\end{array}$} & 26.74 & 20.65 & 19.68 & 22.04 & 13.81 & 10.82 & 11.79 & 11.42 \\
\hline & 0.000 & 0.000 & 0.000 & 0.000 & 0.000 & 0.000 & 0.000 & 0.000 \\
\hline
\end{tabular}

ship categories hence reflect the log point differential effect relative to state ownership.

Column 1 reports a base estimate where just the two factors, labor and capital, are included. The labor coefficient is relatively small and not statistically significant, but as we will show, it is larger and significant in the more preferred models that we present in columns 5 to 8 . Column 2 adds in the ratio of exports to sales, and this variable enters positively and significantly. Columns 3 and 4 introduce the competition variable, defined as 1 if the firm has three or more competitors and 0 otherwise. Entered alone with the inputs, the coefficient is positive but small and insignificant. This is also the case when competition is entered alongside the export share and controlling for inputs. The coefficient on the export share remains large and highly significant. Columns 5 to 8 introduce the ownership variables. In these specifications, the labor and capital coefficients are both positive and statistically significant, and their sum approaches unity. It is of interest to note that the coefficients on both the privatized and new private firms are negative and, in the latter case, marginally significant in two of the four specifications. By contrast, foreign ownership has a large and positive coefficient that is significant at the $1 \%$ level. The positive effect of foreign ownership is maintained, but the significance of the negative effect of new private ownership disappears when the export share and competition variables are entered. Interestingly, when we control for ownership, the export share variable loses all significance, suggesting that studies of the export effect that do not control for firm (especially foreign) ownership may be detecting a spurious effect of exporting on firm performance. In columns 7 and 8, where most or all the explanatory variables are entered simultaneously, we find that competition has a positive and significant (at the $10 \%$ to $11 \%$ level) impact on performance, with foreign ownership exerting a strong and positive impact on performance as well. Being privatized or being a new private firm remains negatively signed but insignificant relative to the reference of state-owned firms. The augmented specifications in columns 5 to 8 also generate acceptable values of the $J$ - and $F$ tests related to the selection of IVs in the first stage of estimation. Our preferred (all-encompassing) specification in column 8 points to the importance of foreign ownership and (to a lesser extent) competition on performance. The corresponding value-added regressions, reported in table A1 in the appendix, yield qualitatively similar results except that the estimated coefficient on competition, while positive, is not statistically significant. ${ }^{19}$

\footnotetext{
${ }^{19}$ Henceforth, we do not report additional value-added regressions as they are based on a smaller sample and a noisy measure of material inputs, and generally yield results that are similar to those in the revenue regressions.
} 
Having estimated the base performance equation, we proceed to considering the impact of business environment constraints on firm performance. Throughout the analysis, we use for each constraint the average value of responses of other firms in the same two-digit sector, firm size (small, medium, and large), country, and year. The other unreported specifications yield similar results. Entering all fifteen categories of constraints invariably yields insignificant estimates, and the question naturally arises as to whether collinearity across constraints induces this insignificance of results. We have examined the relationships among the various constraints and find that most constraints are not highly correlated, although several pairs display high correlation (such as access to financing and cost of financing, tax rates and tax administration, uncertainty about regulatory policies and macroeconomic instability, and street crime and organized crime). This pair-wise correlation is also detected in an ANOVA regression that we have run to assess the extent to which the variation in the value of any given constraint can be explained by the other constraints. In what follows, we enter only one of each of these pair-wise correlated constraint variables, noting that it generally does not matter which of the two is entered. We also exclude the constraint related to labor regulation, as it is almost completely explained by the interaction of country and year fixed effects. This leaves us with nine constraints whose effects we analyze in the remainder of the paper. As may be seen from table A2, the partial correlation coefficients among these nine constraints are relatively low, and the total $R^{2}$ in the reported regressions of each constraint on others is at or below 0.4 in all except one regression (corruption), where it is at 0.51 . When we add country, year, and sector fixed effects to the regressions in table $\mathrm{A} 2$, we increase the $R^{2}$ in the constraints regressions to 0.42-0.59. Finally, adding all other regressors from the IV revenue regressions raises the $R^{2}$ to $0.42-0.59$. Collinearity among the constraints is hence limited.

Table 3 provides a first pass at including the nine constraints in the performance regression: individually (columns 1-9), as an average of all fifteen constraints (column 10), and with all nine constraints entered together (column 11). Despite the obvious omitted variable problem, we report the specifications with the constraints entered one at a time because this approach has been used frequently in the literature, and much of the accepted wisdom on the effects of institutions and regulation on performance derives from these types of specifications. In line with a large part of the literature, the regressions in table 3 are without country, year, and sector fixed effects. (This model appears to be misspecified compared to a model in table 4, which includes these fixed effects, in that the labor coefficient is small and insignificant, and the $p$-values on the $J$-test are very small.) It can be seen that when entered individually, all constraints except one enter negatively, as would be expected from the existing literature, and most are significant at $1 \%$ or $5 \%$ test levels. In these specifications, we replicate the conventional wisdom obtained in many studies that the business or institutional environment matters and that more severe constraints result in poorer performance. The regression with the average value of all fifteen constraints, a proxy for the overall severity of the business environment, also yields a negative and statistically significant coefficient.

When all the constraints are entered simultaneously in the IV estimation in table 3, however, the infrastructure and, to a lesser extent, tax rate and macro instability constraints remain negative and significant, but others lose significance or, in the case of crime, theft, and disorder, become positive and significant, which is counterintuitive. Hence, when we correct at least in part for the possible omitted variables problem, the negative effect of most business environment constraints on performance disappears. As may be seen from table A3, the corresponding ordinary least squares (OLS) estimates are very similar for the individually entered constraints (columns 1-10), and they differ only slightly when all the constraints are entered simultaneously (column 11) in that four of the nine constraints retain a negative coefficient.

Table 4 repeats the same exercise but includes country, year, and sector fixed effects whose omission may have biased the estimates in table 3 . In this case, the significance of the coefficients on inputs, ownership, exports, and competition is similar to those in the base estimations in table 2: foreign ownership and having three or more competitors exert a positive and significant impact, while export orientation does not, and the effect of new private firms becomes negative and statistically significant in some specifications. However, the picture changes substantially with respect to the business environment constraints. While most of the constraints entered individually retain their negative coefficient, only one, on corruption, is statistically significant. The effect of the average of all constraints, reported in column 10, is statistically insignificant, as are all the constraint coefficients in column 11, where all constraints are entered simultaneously. The corresponding OLS estimates in table A4 are similar in that only one constraint - this time, crime, theft, and disorder-has a significant negative coefficient when the constraints are entered individually, and only one has a significant (but positive) coefficient when all the constraints are entered simultaneously. An examination of the role played by the country, year, and sector effects indicates that it is the country as well as country with year fixed effects, in particular, that serve to knock out the significance of the individual (and, in the case of OLS, also the jointly entered) constraints. Hence, once we control for country-wide differences in the business environment (together with aggregate shocks and all other differences), the negative effects of virtually all constraints disappear.

Our findings in tables 3 and 4 are striking in their contrast to the literature and accepted wisdom. We have therefore performed a variety of robustness checks and analytical extensions that we report in the remainder of the paper. As we show, our basic findings remain unaltered. 


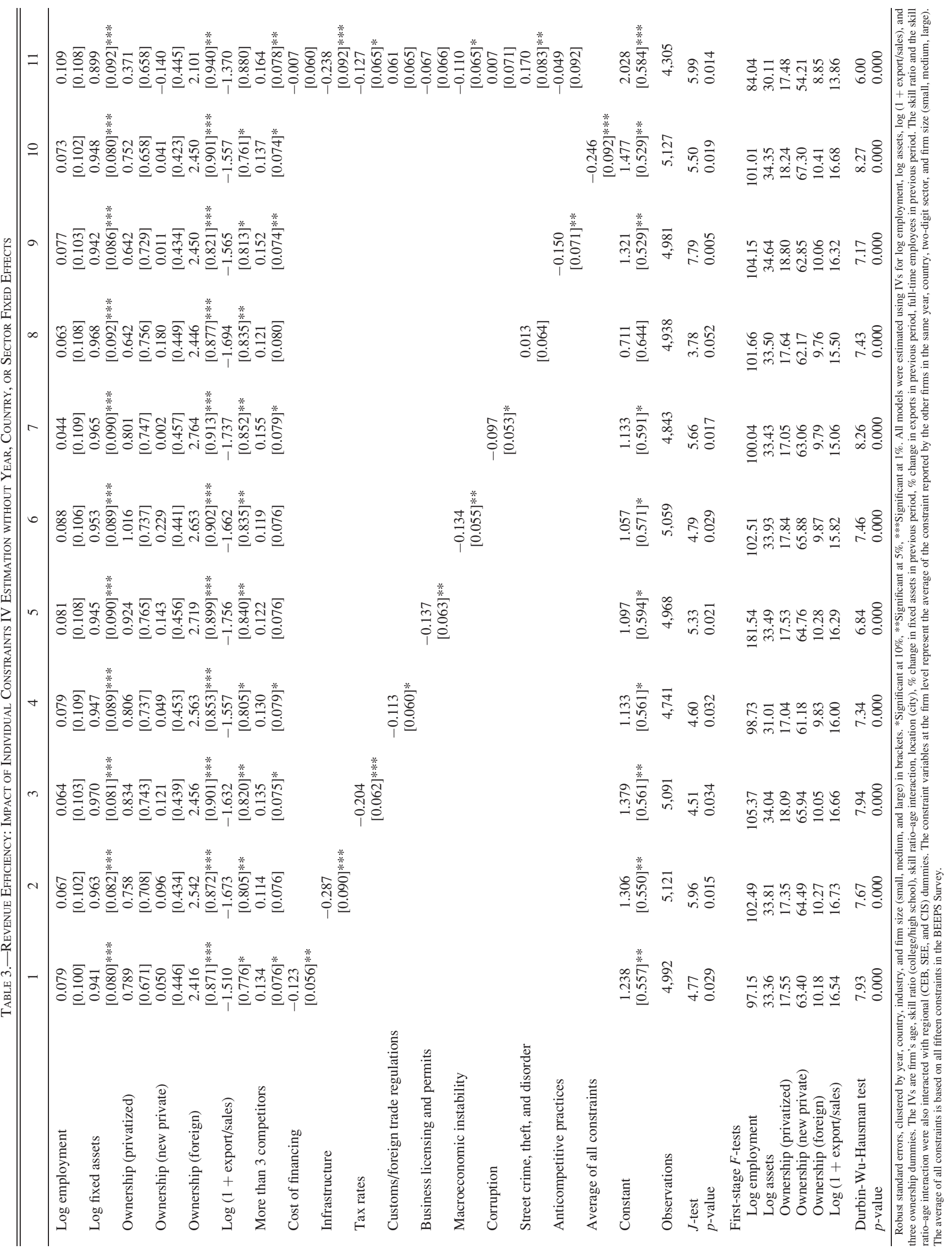




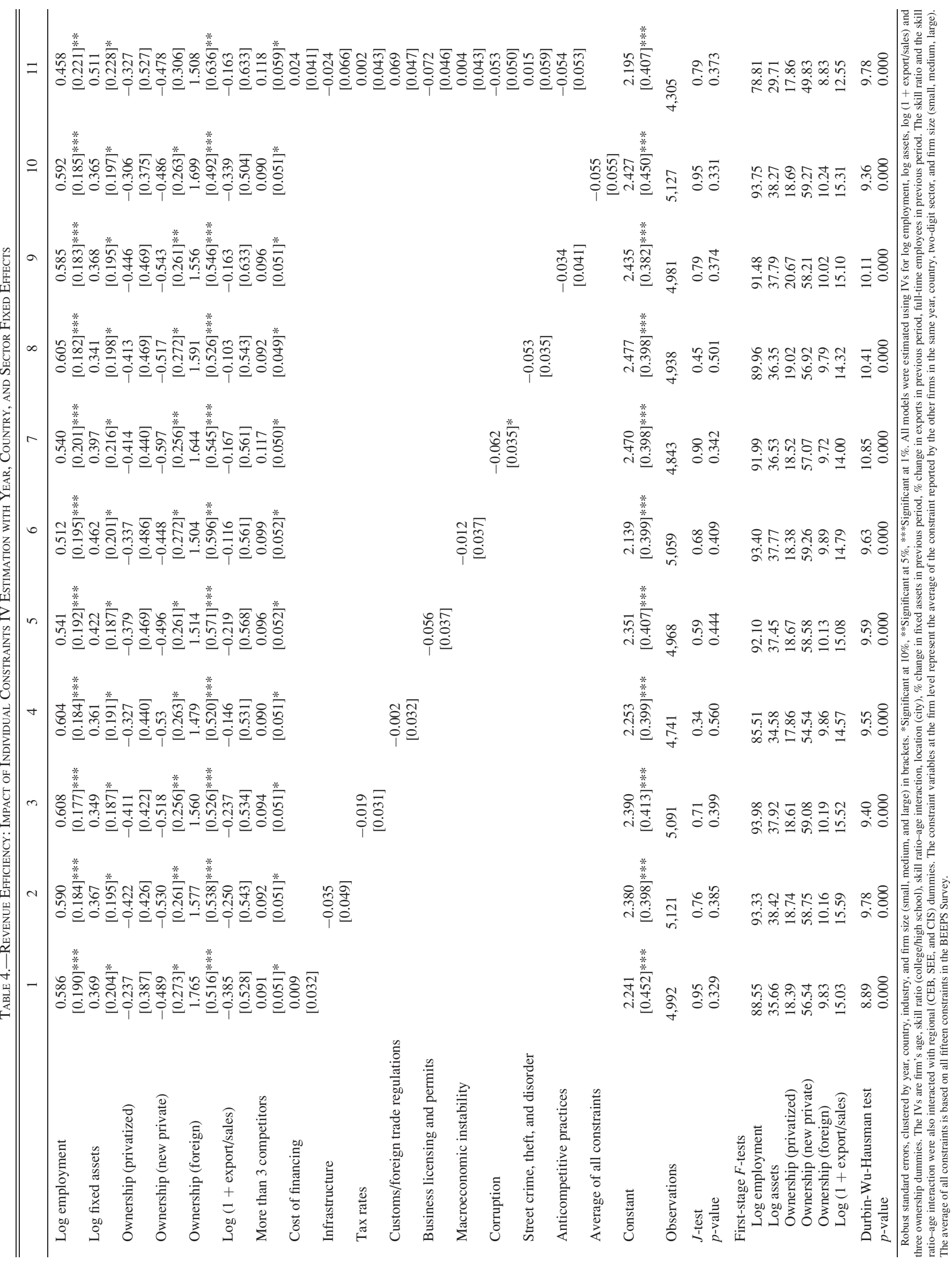


Our first set of analytical extensions relates to the reporting of constraints. It is possible that different respondents center their ratings of constraints differently (for example, some are tougher and some are more benevolent evaluators). It might also be that some respondents use the entire range of possible answers, while others tend to use more the middle of the range (on a scale from 1 to 4 , some respondents might use only 2 and 3 as an answer, whereas others might use the whole range from 1 to 4 ). In tables A5 and A6, we check the robustness of our results from tables 3 and 4 against these possible behavioral patterns. In particular, we subtract the individual firm's average value of all fifteen constraints from each reported constraint and divide the result by the standard deviation of all answers of the firm (that is, we control for attitude as well as the fact that some people might use the full range of available answers while others might not). In both tables, we also include the average value of all constraints in each firm as a regressor to assess the part played by the average reported severity of constraints and the deviation of individual constraints from this mean level. As may be seen from tables A5 and A6, the estimates based on the standardized constraint variables lead to the same conclusions as the results in tables 3 and 4. In particular, estimates without country, sector, and year fixed effects (table A5) suggest that the average level of constraints reported by each firm has a negative effect on performance. Moreover, the coefficients on most individual constraints entered one at a time are insignificant; two are negative and one is positive. When the constraints are entered jointly, three coefficients are negative, and six are insignificant. Taking into account the negative coefficient on the average of all constraints, these results parallel the findings in table 3 that constraints have a negative effect on performance. When the country, sector, and year fixed effects are included (table A6), the effect of the average level of constraints of each firm becomes insignificant, suggesting that the previously significant effect was picking up the country-sector-year effect. Moreover, only one individual constraint (tax rates) has a negative effect regardless of whether the constraints are entered one at a time or jointly. The results in table A6 hence parallel the findings in table 4 and indicate that once we control for fixed country, sector, and time differences, the negative effects of virtually all business environment constraints disappear.

Our second robustness check entails estimating equation (1) in the form of the Solow (TFP) residual and thus avoiding the need to instrument the input variables. These OLS results, estimated without country, sector, and year fixed effects, are reported in table A7. As may be seen from this table, when the constraints are entered one at a time or simultaneously, five of the nine coefficients are significantly negative, two are insignificant, and two (on customs/foreign trade regulations and on anticompetitive practices) are positive. The coefficient on the average of all constraints (column 10) is statistically insignificant. When we replicate the estimation with country, sector, and year fixed effects, three coefficients are negative, five are insignificant, and one is positive. ${ }^{20}$ The Solow (TFP) residual approach hence generates broadly similar results to those reported in tables 3 and 4, with fewer estimated coefficients being significant in the specification with country, sector, and year effects.

We have also extended the analysis by looking at the possible impact that interactions of constraints might have on performance, in line with recent explorations in the development literature (see Aghion et al., 2005, 2006). The intuition here is that, say, corruption may or may not have a direct impact itself, but it may exert an effect through its association with other constraints related to government policies and regulations, such as the functioning of the judiciary, uncertainty about regulatory policies, labor regulations, business licensing, and tax administration and tax rates. To explore whether this is indeed the case, we have augmented the base model with interactions of constraints that may be hypothesized to be related. For example, we have interacted corruption with functioning of the judiciary, uncertainty about regulatory policies, labor regulations, business licensing, and tax administration and tax rates. Neither when the interactions are entered one at a time nor when they are all entered simultaneously do we find statistically significant results. ${ }^{21}$ This example is representative in that we are unable to find any robust evidence for other interactions either.

In another set of extensions, we have explored the idea of heterogeneity across regions and examined whether significant results can be obtained if we estimate the models separately within each of the three main regions covered by our data: Central Europe and the Baltics (CEB), southeastern Europe (SEE), and the CIS. The findings from these estimations allow the slope coefficients to vary by region, and the results are similar to those presented for the sample as a whole. When the country, year, and sector fixed effects are excluded, few constraints are significant, and a number of the signs are counterintuitive. When the country, year, and sector fixed effects are included, virtually all constraints lose significance.

One important result that we are obtaining in our analysis is that country differences, presumably in the overall business environment but also in other aspects, matter for firm performance, while the within-country cross-firm differences do not. Closer inspection of the country fixed effects reveals that while not all are significant, the ranking of countries corresponds to a significant extent to what might be expected from other measures, such as the EBRD transition indicators. ${ }^{22}$ That is, the ranking, for instance, mostly confirms that firms in the Central European countries have higher average levels of efficiency than those from either SEE or the CIS. However, the rankings are not stable and have a number of unexpected features. For instance,

\footnotetext{
20 These results may be obtained from the authors on request.

21 These results may be obtained from the authors on request.

22 See EBRD $(1995,1999)$.
} 
Serbia and Macedonia consistently rank above the most economically advanced (new EU) countries such as the Czech Republic, Hungary, and Poland. This suggests that the country effects are also capturing other sources of heterogeneity, such as differences in accounting and reporting systems. For these very reasons, it is desirable to control for country effects, realizing that they capture many features of heterogeneity, rather than excluding them or attributing the cross-country heterogeneity to just a single factor, such as a particular aspect of the business environment.

Finally, in order to check if the results are by chance driven by the particular sample of firms that we use, we have also carried out some of the key estimations on the AMADEUS data set that contains information on over 150,000 firms in eight transition countries during the period 1997 to 2006. ${ }^{23}$ Although AMADEUS does not exactly replicate the variables available in the BEEPS, it does allow us to estimate very similar specifications to those used above. Table 5 replicates the estimations reported for BEEPS in table A4, using the AMADEUS sample. The constraints variables at the firm level are again the BEEPS average constraints for the same country, two-digit sector, and firm size. It can be seen that when entered individually none of the constraints variables is significant. When entered jointly, only one variable, tax rates, enters significantly and with the predicted sign. The remaining constraints are insignificant, with one (macroeconomic instability) being significant but perversely signed. The main results hence do not appear to be driven by any peculiarity of the BEEPS sample of firms.

\section{B. Using Doing Business and Heritage Foundation Indicators}

In view of our findings based on manager perceptions of the business environment, a question arises as to whether the findings are robust in that other measures of the business and institutional environment would produce similar results. To answer this question, we have examined the effects that widely used indices of the business environment and institutions have when combined with our BEEPS firmlevel data. ${ }^{24}$ In particular, we have merged our firm-level data with twelve of the Doing Business indicators produced by the World Bank. These are the number of procedures to register a business, time to register a business, cost of registering a business, rigidity of employment regulations, restrictions on firing workers, cost of firing a worker, number of procedures to enforce a contract payment after default, time to enforce a contract payment after default, cost of enforcing a contract payment after default, time to effectuate bankruptcy, cost of effectuating bankruptcy, and recovery rate in a bankruptcy. As an alternative, we have

\footnotetext{
${ }^{23}$ The countries are Bulgaria, Croatia, Czech Republic, Estonia, Latvia, Lithuania, Poland, and Ukraine.

${ }^{24}$ We thank John DiNardo for suggesting this analytical extension to us.
}

also used the ten indices of economic freedom produced by the Heritage Foundation: trade tariffs, tax rates, government intervention, monetary policy (inflation), restrictions on foreign direct investment, banking and finance sector restrictions, wage and price controls, property rights issues, business and other regulations, and the extent of informal markets. The Doing Business indicators are on a 1 to 100 scale or have a natural value (days, number of procedures, and so on), while the Heritage Foundation indices are measured on a 1 to 5 scale $(1=$ best or most free and $5=$ worst or least free). The data for the Heritage Foundation relate to 2001 and 2004, while those for Doing Business were published in 2003 and 2006 (and collected mostly in 2002 and $2005)^{25}$

A major issue that arises in all studies using the Doing Business and Heritage Foundation indicators is that the values of these indicators are highly correlated over time. For the two years that we use, the Heritage Foundation indicators for our 27 countries have a correlation that ranges between 0.91 (government intervention) and 0.99 (business and other regulation). This means that the indicators are close to being indistinguishable from country fixed effects. The Doing Business indicators are potentially more interesting than the Heritage Foundation indices for the fixedeffects regressions because some are less correlated over time; the correlation coefficients range from 0.84 for time to start a business to almost 1.0 for contracts procedures. Yet as may be seen from table 6, when we enter the Doing Business indicators individually into the IV regressions with country, industry, and year fixed effects, only three coefficients are negative, two are positive, and seven are statistically insignificant. When we enter the indicators simultaneously, four are negative and eight are insignificant. Of the three indicators that have a correlation of the 2003 and 2006 values below 0.9 (time to register a business, cost of registering a business, and restrictions on firing workers), two generate a negative effect and one a positive effect when entered individually, while one produces a negative coefficient and two produce an insignificant coefficient when entered simultaneously. In the IV regressions without the fixed effects (not reported in a tabular form here), only two of the twelve constraints have a negative effect.

In view of the space constraints, we briefly report the remaining results in this area without the corresponding tables. ${ }^{26}$ When we enter the Doing Business indicators one at a time into OLS regressions without country, industry, and year fixed effects, we obtain seven coefficients that are negative, three that are positive, and two that are statistically insignificant. When all the business environment indicators are entered simultaneously, six coefficients are negative, five are positive, and one is statistically insignificant. Hence, even in the OLS specification without fixed country,

\footnotetext{
25 "Doing Business" was first published in 2003.

26 They may be obtained from the authors on request
} 


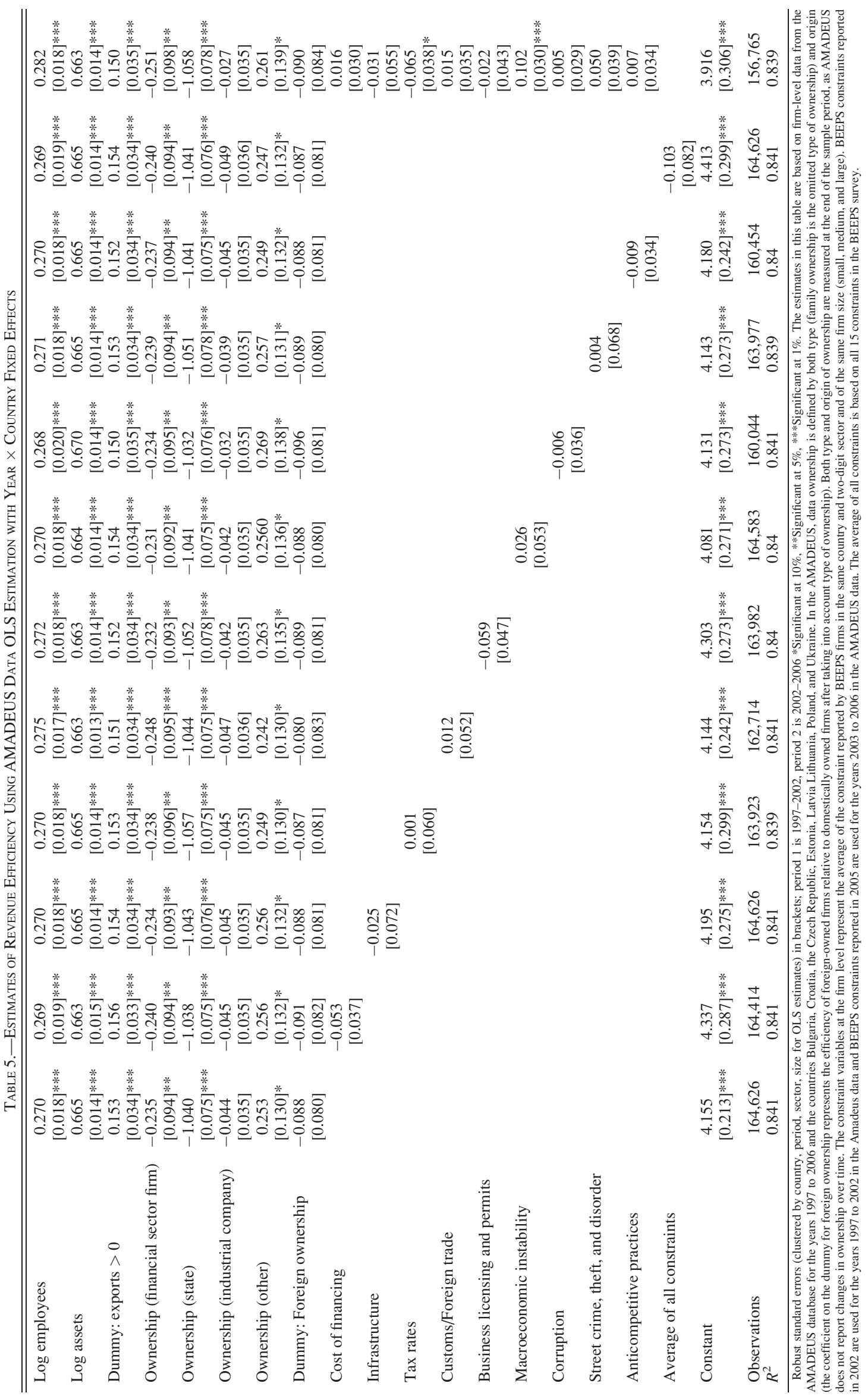




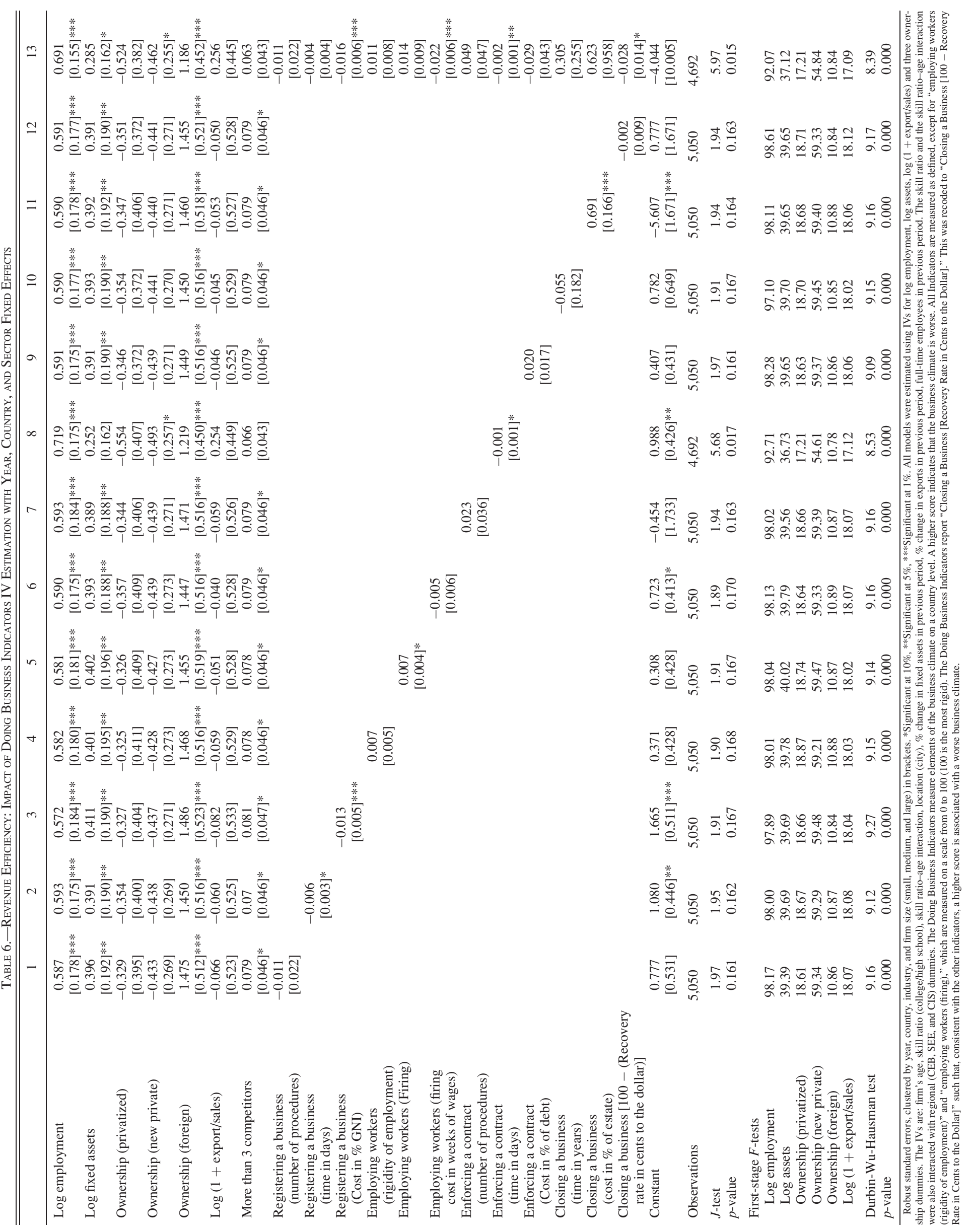


sector, and year effects, the Doing Business indicators provide surprisingly limited support for the traditional hypothesis that constraints have a negative effect on performance, and the support is even weaker in the OLS specification with fixed effects and in the IV specifications.

The Heritage Foundation indicators of regulation generate results that are more in line with the existing literature and our findings in tables 3 and 4 . When we enter the Heritage Foundation indicators one at a time into our OLS regressions without country, industry, and year fixed effects, the indices all produce the expected negative effects of regulation or constraints on firm performance, as does a simple average index of these ten indices. When the ten indices are entered simultaneously, five retain negative coefficients, two coefficients turn positive, and three become statistically insignificant. Our data hence reproduce the traditional result that when the Heritage indicators are entered one at a time in an OLS regression, they show a strong negative effect of regulation on performance. The effects are quite mixed, however, when the indicators are entered jointly. The fact that the Heritage Foundation indicators are highly correlated over time is reflected in the OLS estimates with country, industry, and year fixed effects. When the Heritage Foundation indicators are entered one at a time, only two of the ten indicators retain negative coefficients, one becomes positive, and seven become statistically insignificant. When all the indicators are entered simultaneously, two coefficients are negative, three are positive, and five are insignificant. When we use the Heritage Foundation indicators in our IV regressions, with or without country, industry, and year fixed effects, the coefficients of the individual Heritage Foundation indicators all become insignificant when entered individually, and they produce three negative, one to three positive, and four to six insignificant coefficients when entered simultaneously. Moreover, the coefficients that are negative are not the same ones in the various specifications. In sum, specifications other than a simple OLS model with each Heritage Foundation constraint entered individually basically fail to generate the expected negative effect of regulation or constraints indicators on firm performance. $^{27}$

Overall, our results indicate that the widely used countrylevel indicators of business and institutional environment do not provide much evidence of a negative relationship between the constraining environment and firm performance. Some of these indicators, particularly the Heritage Foundation indices, produce evidence consistent with this hypothesis in the simplest OLS specifications when the indices are entered one at a time, but not in the specifica-

\footnotetext{
27 The power of the tests is obviously low in those instances when we are exploiting the limited variation in the values of these indices over time and one might not be rejecting the null hypothesis of no effects of the constraints even when this null hypothesis is false. The point that we are making is simply that with the indicators at hand, one does not generate the expected negative effect when controlling for cross-country heterogeneity.
}

tions when the indices are entered jointly or models that control for other relevant factors.

\section{Rate of Growth of Revenues}

Having looked at the effects of the constraints and the structural variables capturing ownership, export orientation and competition on the level of revenue efficiency, we next address the question of whether these variables have any effect on the rate of change in the revenue efficiency of firms. These initial value regressions are estimated on the smaller number of firms in the BEEPS panel data set. We have checked the comparability of the panel to the larger data set by comparing summary statistics and have also replicated on the panel data the same base estimations as we present for the pooled cross-sectional data in table 2 . These base estimations performed on the panel data are reported in table A8.

In table 7 we present the results of relating the 20022005 rate of change of real sales revenues to the lagged (2002) levels of the ownership, competition, export orientation, and constraint variables, controlling for the rate of change in labor and capital over the same period. By construction, these initial value regressions eliminate the possibility that the relationship between efficiency, constraints, and the structural variables is brought about by contemporaneous shocks to these variables. Estimation in this instance is by OLS with country, sector, and year fixed effects included. While foreign ownership enters positively, and the coefficient on new private ownership tends to be negative as before, we do not find evidence for any type of ownership having a statistically significant impact on the rate of change of performance. Export orientation enters positively and is mostly statistically insignificant, and we are unable to find any impact from competition. As to the business and institutional constraints, none of the variables generates a significant negative effect, whether entered individually or jointly and the size of the estimated coefficients tends to be small. We hence find no evidence that the level of perceived constraints matters for subsequent rate of change of performance. In particular, the different aspects of the business environment, as measured by these reported constraints, do not affect the subsequent rate of change of efficiency with which firms generate revenue from inputs.

\section{What Matters for Firm Performance?}

Given that indicators of the business environment have been widely used by both international organizations, such as the World Bank, and national development assistance agencies, such as the U.S. Agency for International Development, in formulating key policies and awarding large amounts of assistance, our finding that one cannot detect significant effects of these indicators on firm performance is sobering. Since development funds may be used for alternative policies, our result also raises the issue of whether indi- 


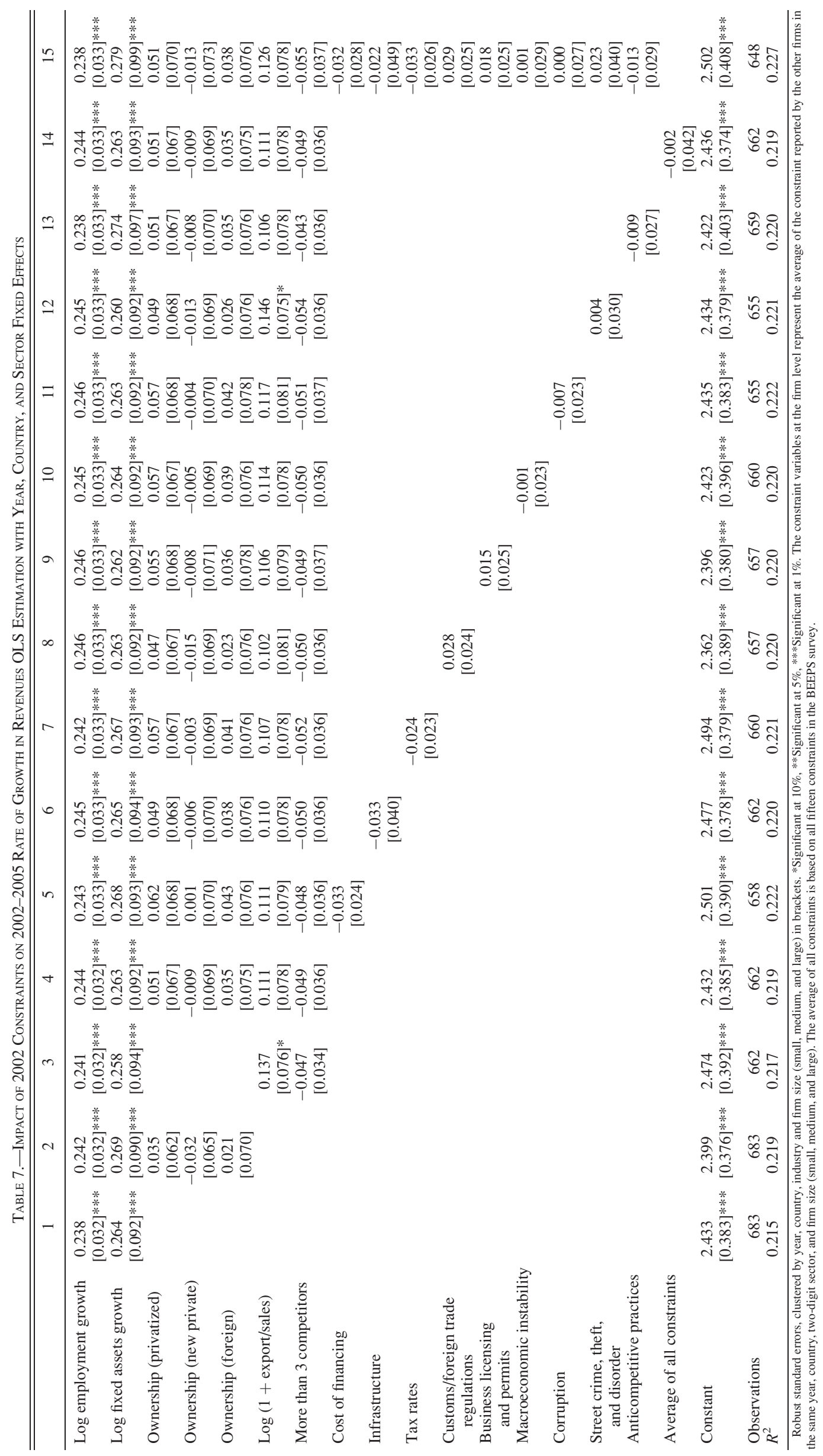


Table 8.-Revenue EfFiciency-Impact of Individual Constraints and Parameterization of Unobserved Heterogeneity

\begin{tabular}{|c|c|c|c|c|c|c|c|c|}
\hline & $\begin{array}{l}\text { Individual } \\
\text { Constraints } \\
\text { (1) }\end{array}$ & $\begin{array}{c}\text { All } \\
\text { Constraints } \\
\text { (2) }\end{array}$ & $\begin{array}{l}\text { Individual } \\
\text { Constraints } \\
\text { (3) }\end{array}$ & $\begin{array}{c}\text { All } \\
\text { Constraints } \\
\text { (4) }\end{array}$ & $\begin{array}{l}\text { Individual } \\
\text { Constraints } \\
\text { (5) }\end{array}$ & $\begin{array}{c}\text { All } \\
\text { Constraints } \\
\text { (6) }\end{array}$ & $\begin{array}{l}\text { Individual } \\
\text { Constraints } \\
\text { (7) }\end{array}$ & $\begin{array}{c}\text { All } \\
\text { Constraints } \\
\text { (8) }\end{array}$ \\
\hline Cost of financing & $\begin{array}{c}-0.168 * * * \\
{[0.060]}\end{array}$ & $\begin{array}{c}-0.057 \\
{[0.064]}\end{array}$ & $\begin{array}{c}-0.021 \\
{[0.037]}\end{array}$ & $\begin{array}{c}-0.013 \\
{[0.046]}\end{array}$ & $\begin{array}{c}-0.174 * * * \\
{[0.056]}\end{array}$ & $\begin{array}{c}-0.061 \\
{[0.065]}\end{array}$ & $\begin{array}{c}-0.002 \\
{[0.073]}\end{array}$ & $\begin{array}{c}0.031 \\
{[0.056]}\end{array}$ \\
\hline Infrastructure & $\begin{array}{c}-0.337 * * * \\
{[0.099]}\end{array}$ & $\begin{array}{c}-0.303 * * * \\
{[0.102]}\end{array}$ & $\begin{array}{c}-0.042 \\
{[0.055]}\end{array}$ & $\begin{array}{c}-0.007 \\
{[0.069]}\end{array}$ & $\begin{array}{c}-0.372 * * * \\
{[0.108]}\end{array}$ & $\begin{array}{c}-0.299 * * \\
{[0.108]}\end{array}$ & $\begin{array}{c}-0.060 \\
{[0.117]}\end{array}$ & $\begin{array}{c}-0.062 \\
{[0.115]}\end{array}$ \\
\hline Tax rates & $\begin{array}{c}-0.225 * * * \\
{[0.066]}\end{array}$ & $\begin{array}{c}-0.117 \\
{[0.074]}\end{array}$ & $\begin{array}{c}-0.030 \\
{[0.035]}\end{array}$ & $\begin{array}{c}0.019 \\
{[0.049]}\end{array}$ & $\begin{array}{c}-0.239 * * * \\
{[0.067]}\end{array}$ & $\begin{array}{c}-0.134 * \\
{[0.049]}\end{array}$ & $\begin{array}{c}-0.058 \\
{[0.067]}\end{array}$ & $\begin{array}{c}-0.081^{*} \\
{[0.048]}\end{array}$ \\
\hline Customs/foreign trade regulations & $\begin{array}{c}-0.127 * \\
{[0.067]}\end{array}$ & $\begin{array}{c}0.062 \\
{[0.070]}\end{array}$ & $\begin{array}{c}-0.003 \\
{[0.036]}\end{array}$ & $\begin{array}{c}0.075 \\
{[0.051]}\end{array}$ & $\begin{array}{c}-0.126^{*} \\
{[0.067]}\end{array}$ & $\begin{array}{c}0.067 \\
{[0.050]}\end{array}$ & $\begin{array}{c}0.012 \\
{[0.069]}\end{array}$ & $\begin{array}{c}0.089^{*} \\
{[0.067]}\end{array}$ \\
\hline Business licensing and permits & $\begin{array}{c}-0.149 * * \\
{[0.071]}\end{array}$ & $\begin{array}{c}-0.053 \\
{[0.076]}\end{array}$ & $\begin{array}{c}-0.083^{*} \\
{[0.045]}\end{array}$ & $\begin{array}{c}-0.091 \\
{[0.056]}\end{array}$ & $\begin{array}{r}-0.150^{*} \\
{[0.069]}\end{array}$ & $\begin{array}{c}-0.052 \\
{[0.050]}\end{array}$ & $\begin{array}{c}-0.038 \\
{[0.052]}\end{array}$ & $\begin{array}{c}-0.056 \\
{[0.056]}\end{array}$ \\
\hline Macroeconomic instability & $\begin{array}{c}-0.175 * * * \\
{[0.060]}\end{array}$ & $\begin{array}{c}-0.124^{*} \\
{[0.070]}\end{array}$ & $\begin{array}{c}-0.055 \\
{[0.048]}\end{array}$ & $\begin{array}{c}-0.023 \\
{[0.049]}\end{array}$ & $\begin{array}{c}-0.172^{* *} \\
{[0.061]}\end{array}$ & $\begin{array}{c}-0.113^{*} \\
{[0.048]}\end{array}$ & $\begin{array}{c}-0.043 \\
{[0.048]}\end{array}$ & $\begin{array}{c}-0.052 \\
{[0.053]}\end{array}$ \\
\hline Corruption & $\begin{array}{c}-0.096 \\
{[0.060]}\end{array}$ & $\begin{array}{c}0.020 \\
{[0.082]}\end{array}$ & $\begin{array}{c}-0.072 * \\
{[0.041]}\end{array}$ & $\begin{array}{c}-0.044 \\
{[0.056]}\end{array}$ & $\begin{array}{c}-0.091 \\
{[0.059]}\end{array}$ & $\begin{array}{c}0.040 \\
{[0.079]}\end{array}$ & $\begin{array}{c}-0.009 \\
{[0.042]}\end{array}$ & $\begin{array}{c}-0.008 \\
{[0.042]}\end{array}$ \\
\hline Street crime, theft, and disorder & $\begin{array}{c}0.031 \\
{[0.071]}\end{array}$ & $\begin{array}{l}0.227 * * \\
{[0.094]}\end{array}$ & $\begin{array}{c}-0.068^{*} \\
{[0.041]}\end{array}$ & $\begin{array}{c}0.006 \\
{[0.065]}\end{array}$ & $\begin{array}{c}0.035 \\
{[0.074]}\end{array}$ & $\begin{array}{l}0.231 * * \\
{[0.065]}\end{array}$ & $\begin{array}{c}-0.035 \\
{[0.043]}\end{array}$ & $\begin{array}{c}0.019 \\
{[0.043]}\end{array}$ \\
\hline Anticompetitive practices & $\begin{array}{c}-0.185^{* *} \\
{[0.077]}\end{array}$ & $\begin{array}{c}-0.090 \\
{[0.101]}\end{array}$ & $\begin{array}{c}-0.057 \\
{[0.050]}\end{array}$ & $\begin{array}{c}-0.049 \\
{[0.057]}\end{array}$ & $\begin{array}{c}-0.208 * * * \\
{[0.080]}\end{array}$ & $\begin{array}{c}-0.113 \\
{[0.099]}\end{array}$ & $\begin{array}{c}0.008 \\
{[0.101]}\end{array}$ & $\begin{array}{c}0.031 \\
{[0.101]}\end{array}$ \\
\hline Year, country, and sector fixed effects & No & No & Yes & Yes & No & No & No & No \\
\hline Log GDP per capita & No & No & No & No & No & No & Yes & $\begin{array}{l}0.442 * * \\
{[0.199]}\end{array}$ \\
\hline Tertiary school enrollment (\%) & No & No & No & No & Yes & $\begin{array}{c}0.078 \\
{[0.432]}\end{array}$ & Yes & $\begin{array}{c}0.071 \\
{[0.197]}\end{array}$ \\
\hline Health expenditure/GDP (\%) & No & No & No & No & Yes & $\begin{array}{c}-0.004 \\
{[0.045]}\end{array}$ & Yes & $\begin{array}{c}0.040 \\
{[0.028]}\end{array}$ \\
\hline $\begin{array}{l}\text { Observations } \\
R^{2}\end{array}$ & & $\begin{array}{l}3,727 \\
0.389\end{array}$ & & $\begin{array}{c}3,727 \\
0.696\end{array}$ & & $\begin{array}{l}3,727 \\
0.366\end{array}$ & & $\begin{array}{l}3,727 \\
0.695\end{array}$ \\
\hline
\end{tabular}

Robust standard errors, clustered by year, country, industry and firm size (small, medium, and large) in brackets. *Significant at 10\%,**Significant at $5 \%$, ***Significant at $1 \%$. All columns report coefficients of IV regressions of $\log$ sales on $\log ($ employment), $\log$ (assets), $\log$ (1+exports/sales), ownership variables, a dummy for more than three competitors, and contraints. To save space, we decided not to report the point estimates of those variables. Results are similar to those found in tables 3 and 4 . Individual refers to a regression of the dependent variable on the regressors mentioned above and the individual constraint specified in that row.

cators of other externally supported development policies yield similarly insignificant or significant effects on performance. While an elaborate treatment of this topic is beyond the scope of this paper, we take a step toward answering this question by exploring whether indicators that have been found to be significant in explaining performance at a country level, such as country-wide tertiary school enrollment or expenditures on health care relative to GDP, also have a significant effect on firm performance, relative to the business environment constraints. As a first-order approximation, one may think of these two alternative indicators as proxies for allocating development funds to improvements in human capital as opposed to the business environment.

In tables 8 and 9 we use the BEEPS data and the BEEPs data merged with the Doing Business indicators, respectively, to generate IV estimates of the performance effects of the business environment, tertiary school enrollment, expenditures on health care scaled by GDP, and GDP per capita. The data set is somewhat smaller than the one used earlier because of missing observations on tertiary school enrollment or health care expenditure, or both, in some countries. Hence, for consistency of exposition, the first two columns of each table report the baseline IV regressions without fixed effects. Columns 3 and 4 report the corresponding regressions with year, country, and sector fixed effects. Columns 5 and 6 add tertiary school enrollment and per capita GDP expenditures on health care to the specification of columns 1 and 2, thus providing a direct test of the relative importance of business constraints, tertiary school enrollment, and health care expenditure per GDP on performance. Finally, in columns 7 and 8, we add GDP per capita as a regressor to these equations to assess whether this overall proxy of economic development is a better or worse predictor of firm performance than the other variables. Columns titled "Individual Constraints" refer to regressions that contain one constraint at a time. In these columns, each row corresponds to a different regression. Columns titled "All Constraints" report a single regression in which all the constraints are entered simultaneously.

Starting with the BEEPs data in table 8, we see that in columns 1 to 4 , we largely replicate our earlier findings from tables 3 and 4 . When we enter the tertiary school enrollment and health care explanatory variables in addition to the business environment constraints, we find in columns 5 and 6 that the estimated effects of the business constraints are by and large unaffected and the education and health care effects are also insignificant. When we add GDP per capita as a regressor, we observe a positive effect of GDP per capita, while the effects of the business environment constraints become by and large insignificant and their loss of significance is especially notable when they are entered one at a time (column 7). The comparison of columns 1 and 
Table 9.-Revenue Efficiency: Impact of Doing Business Indicators and Parameterization of Unobserved Heterogeneity

\begin{tabular}{|c|c|c|c|c|c|c|c|c|}
\hline & $\begin{array}{l}\text { Individual } \\
\text { Constraints } \\
\text { (1) }\end{array}$ & $\begin{array}{c}\text { All } \\
\text { Constraints } \\
\text { (2) }\end{array}$ & $\begin{array}{c}\text { Individual } \\
\text { Constraints } \\
\text { (3) }\end{array}$ & $\begin{array}{c}\text { All } \\
\text { Constraints } \\
\text { (4) }\end{array}$ & $\begin{array}{l}\text { Individual } \\
\text { Constraints } \\
\text { (5) }\end{array}$ & $\begin{array}{c}\text { All } \\
\text { Constraints } \\
\text { (6) }\end{array}$ & $\begin{array}{l}\text { Individual } \\
\text { Constraints } \\
\text { (7) }\end{array}$ & $\begin{array}{c}\text { All } \\
\text { Constraints } \\
\text { (8) }\end{array}$ \\
\hline $\begin{array}{l}\text { Registering a business (number } \\
\text { of procedures) }\end{array}$ & $\begin{array}{l}-0.027 \\
{[0.020]}\end{array}$ & $\begin{array}{c}-0.118 * * \\
{[0.046]}\end{array}$ & $\begin{array}{r}-0.021 \\
{[0.032]}\end{array}$ & $\begin{array}{l}-0.045 \\
{[0.041]}\end{array}$ & $\begin{array}{r}-0.041 * \\
{[0.023]}\end{array}$ & $\begin{array}{c}-0.087 * * \\
{[0.042]}\end{array}$ & $\begin{array}{c}-0.029 * * * \\
{[0.009]}\end{array}$ & $\begin{array}{c}-0.034 \\
{[0.021]}\end{array}$ \\
\hline Registering a business (time in days) & $\begin{array}{l}-0.001 \\
{[0.002]}\end{array}$ & $\begin{array}{c}0.001 \\
{[0.002]}\end{array}$ & $\begin{array}{l}-0.009 * * \\
{[0.004]}\end{array}$ & $\begin{array}{l}-0.031 \\
{[0.025]}\end{array}$ & $\begin{array}{l}-0.001 \\
{[0.002]}\end{array}$ & $\begin{array}{c}0.001 \\
{[0.002]}\end{array}$ & $\begin{array}{c}-0.003 * * \\
{[0.001]}\end{array}$ & $\begin{array}{l}-0.000 \\
{[0.002]}\end{array}$ \\
\hline Registering a business (cost in \% GNI) & $\begin{array}{l}-0.009 * * * \\
{[0.003]}\end{array}$ & $\begin{array}{c}-0.005^{*} \\
{[0.003]}\end{array}$ & $\begin{array}{l}-0.012 * * \\
{[0.006]}\end{array}$ & $\begin{array}{l}-0.007 \\
{[0.011]}\end{array}$ & $\begin{array}{l}-0.009 * * * \\
{[0.003]}\end{array}$ & $\begin{array}{l}-0.004 \\
{[0.003]}\end{array}$ & $\begin{array}{c}0.000 \\
{[0.003]}\end{array}$ & $\begin{array}{r}-0.002 \\
{[0.003]}\end{array}$ \\
\hline $\begin{array}{l}\text { Employing workers (rigidity } \\
\text { of employment) }\end{array}$ & $\begin{array}{l}0.013 * * * \\
{[0.003]}\end{array}$ & $\begin{array}{l}0.012 * * * \\
{[0.004]}\end{array}$ & $\begin{array}{c}0.004 \\
{[0.005]}\end{array}$ & $\begin{array}{c}0.039 \\
{[0.004]}\end{array}$ & $\begin{array}{l}0.013 * * * \\
{[0.004]}\end{array}$ & $\begin{array}{l}0.012 * * \\
{[0.005]}\end{array}$ & $\begin{array}{l}0.005 * * \\
{[0.003]}\end{array}$ & $\begin{array}{c}-0.007 \\
{[0.012]}\end{array}$ \\
\hline Employing workers (firing) & $\begin{array}{c}0.001 \\
{[0.002]}\end{array}$ & $\begin{array}{l}-0.007 * * * \\
{[0.002]}\end{array}$ & $\begin{array}{c}0.005 \\
{[0.004]}\end{array}$ & $\begin{array}{c}-0.042 \\
{[0.044]}\end{array}$ & $\begin{array}{c}-0.001 \\
{[0.007]}\end{array}$ & $\begin{array}{l}-0.009 * * * \\
{[0.002]}\end{array}$ & $\begin{array}{c}0.001 \\
{[0.001]}\end{array}$ & $\begin{array}{c}0.006 \\
{[0.007]}\end{array}$ \\
\hline $\begin{array}{l}\text { Employing workers (firing cost } \\
\text { in weeks of wages) }\end{array}$ & $\begin{array}{l}-0.001 \\
{[0.004]}\end{array}$ & $\begin{array}{c}0.001 \\
{[0.002]}\end{array}$ & $\begin{array}{c}0.009 \\
{[0.013]}\end{array}$ & $\begin{array}{c}-0.067 \\
{[0.047]}\end{array}$ & $\begin{array}{l}-0.001 \\
{[0.013]}\end{array}$ & $\begin{array}{c}0.004 * \\
{[0.013]}\end{array}$ & $\begin{array}{r}-0.003 * \\
{[0.002]}\end{array}$ & $\begin{array}{l}-0.004 \\
{[0.005]}\end{array}$ \\
\hline $\begin{array}{l}\text { Enforcing a contract (number } \\
\text { of procedures) }\end{array}$ & $\begin{array}{r}0.012^{*} \\
{[0.007]}\end{array}$ & $\begin{array}{c}-0.015 \\
{[0.011]}\end{array}$ & $\begin{array}{c}0.076 \\
{[0.055]}\end{array}$ & $\begin{array}{c}-0.071 \\
{[0.079]}\end{array}$ & $\begin{array}{l}0.015^{* *} \\
{[0.007]}\end{array}$ & $\begin{array}{c}0.004 \\
{[0.007]}\end{array}$ & $\begin{array}{l}0.013 * * * \\
{[0.004]}\end{array}$ & $\begin{array}{r}0.015^{*} \\
{[0.006]}\end{array}$ \\
\hline $\begin{array}{l}\text { Enforcing a contract } \\
\text { (time in days) }\end{array}$ & $\begin{array}{c}0.000 \\
{[0.000]}\end{array}$ & $\begin{array}{l}0.002 * * * \\
{[0.000]}\end{array}$ & $\begin{array}{c}-0.000 \\
{[0.002]}\end{array}$ & $\begin{array}{c}0.027 \\
{[0.023]}\end{array}$ & $\begin{array}{c}-0.000 \\
{[0.000]}\end{array}$ & $\begin{array}{l}0.001 * * * \\
{[0.000]}\end{array}$ & $\begin{array}{c}0.000 \\
{[0.000]}\end{array}$ & $\begin{array}{c}0.000 \\
{[0.000]}\end{array}$ \\
\hline $\begin{array}{l}\text { Enforcing a contract } \\
\quad(\text { cost in } \% \text { of debt })\end{array}$ & $\begin{array}{c}-0.003 \\
{[0.014]}\end{array}$ & $\begin{array}{c}-0.020 \\
{[0.012]}\end{array}$ & $\begin{array}{c}0.018 \\
{[0.017]}\end{array}$ & $\begin{array}{c}0.064 \\
{[0.070]}\end{array}$ & $\begin{array}{c}-0.012 \\
{[0.013]}\end{array}$ & $\begin{array}{c}0.003 \\
{[0.012]}\end{array}$ & $\begin{array}{c}-0.006 \\
{[0.017]}\end{array}$ & $\begin{array}{c}-0.002 \\
{[0.013]}\end{array}$ \\
\hline Closing a business (time in years) & $\begin{array}{l}-0.020 \\
{[0.021]}\end{array}$ & $\begin{array}{l}0.070 * * * \\
{[0.026]}\end{array}$ & $\begin{array}{l}-0.376 \\
{[0.253]}\end{array}$ & $\begin{array}{r}-0.313 \\
{[0.406]}\end{array}$ & $\begin{array}{l}-0.019 \\
{[0.253]}\end{array}$ & $\begin{array}{l}0.078 * * * \\
{[0.026]}\end{array}$ & $\begin{array}{l}-0.064 * * * \\
{[0.253]}\end{array}$ & $\begin{array}{r}-0.057 \\
{[0.015]}\end{array}$ \\
\hline Closing a business (cost in $\%$ of estate) & $\begin{array}{l}-0.013 * * * \\
{[0.004]}\end{array}$ & $\begin{array}{l}0.032 * * * \\
{[0.012]}\end{array}$ & $\begin{array}{l}0.543 * * * \\
{[0.209]}\end{array}$ & $\begin{array}{r}-0.068 \\
{[1.134]}\end{array}$ & $\begin{array}{l}-0.017 * * * \\
{[0.004]}\end{array}$ & $\begin{array}{c}0.016 \\
{[0.210]}\end{array}$ & $\begin{array}{l}-0.004 \\
{[0.004]}\end{array}$ & $\begin{array}{c}0.003 \\
{[0.005]}\end{array}$ \\
\hline $\begin{array}{l}\text { Closing a business }[100 \text { - (recovery } \\
\text { rate in cents to the dollar)] }\end{array}$ & $\begin{array}{l}-0.006 \\
{[0.006]}\end{array}$ & $\begin{array}{l}-0.025^{* * * *} \\
{[0.008]}\end{array}$ & $\begin{array}{l}-0.013 \\
{[0.010]}\end{array}$ & $\begin{array}{l}-0.035 \\
{[0.023]}\end{array}$ & $\begin{array}{l}-0.005 \\
{[0.006]}\end{array}$ & $\begin{array}{l}-0.020 * * * \\
{[0.007]}\end{array}$ & $\begin{array}{r}-0.006 * \\
{[0.023]}\end{array}$ & $\begin{array}{l}-0.006 \\
{[0.004]}\end{array}$ \\
\hline Year, country, and sector fixed effects & No & No & Yes & Yes & No & No & No & No \\
\hline Log GDP per capita & No & No & No & No & No & No & Yes & $\begin{array}{l}0.739 * * \\
{[0.338]}\end{array}$ \\
\hline Tertiary school enrollment (\%) & No & No & No & No & Yes & $\begin{array}{l}1.222 * * * \\
{[0.257]}\end{array}$ & Yes & $\begin{array}{c}-0.726 \\
{[0.820]}\end{array}$ \\
\hline Health expenditure/GDP $(\%)$ & No & No & No & No & Yes & $\begin{array}{c}0.052 \\
{[0.042]}\end{array}$ & Yes & $\begin{array}{l}0.144 * * \\
{[0.071]}\end{array}$ \\
\hline $\begin{array}{l}\text { Observations } \\
R^{2}\end{array}$ & & $\begin{array}{l}4,050 \\
0.738\end{array}$ & & $\begin{array}{c}4,050 \\
0.794\end{array}$ & & $\begin{array}{l}4,050 \\
0.767\end{array}$ & & $\begin{array}{l}4,050 \\
0.774\end{array}$ \\
\hline $\begin{array}{l}\text { Robust standard errors, clustered by year, country, in } \\
\text { IV regressions of log sales on log(employment), log (as } \\
\text { estimates of those variables. Results are similar to those } \\
\text { that row. The Doing Business Indicators measure elem } \\
\text { "Employing Workers [Rigidity of Employment]" and " } \\
\text { [Recovery Rate in Cents to the Dollar]." This was reco } \\
\text { worse business climate. }\end{array}$ & $\begin{array}{l}\text { y and firm siz } \\
\text { log }(1+\text { expo } \\
\text { hd in tables } 3 \text {. } \\
\text { of the busines } \\
\text { loying Worke } \\
\text { to "Closing a }\end{array}$ & $\begin{array}{l}\text { ate on a cou } \\
\text { ing)," which } \\
\text { ess [100- }\end{array}$ & $\begin{array}{l}\text { el. A higher } \\
\text { easured on a } \\
\text { ry Rate in Ce }\end{array}$ & $\begin{array}{l}\text { "om } 0 \text { to } 100 \\
\text { the Dollar]" }\end{array}$ & the most ri & $\begin{array}{l}\text { entioned abo } \\
\text { orse. All Ind } \\
\text { e Doing Bus } \\
\text { the other in }\end{array}$ & $\begin{array}{l}\text { \%. All column } \\
\text { e, we decided } \\
\text { the individual } \\
\text { are measured } \\
\text { ndicators repo } \\
\text {, a higher sco }\end{array}$ & $\begin{array}{l}\text { rt coefficients } \\
\text { report the poir } \\
\text { raint specified } \\
\text { fined, except } \mathrm{f} \\
\text { osing a Busines } \\
\text { associated with }\end{array}$ \\
\hline
\end{tabular}

2,3 and 4 , and 7 and 8 suggests that the country fixed effects that eliminate the effect of the individual business constraints are well approximated by intercountry differences in GDP per capita.

In table 9 we carry out the same estimations while replacing the BEEPS manager responses with the Doing Business indicators. The results in this table suggest that tertiary school enrollment or health care expenditures, or both, have a positive effect on firm performance, while the effect of business constraints is mostly insignificant; in the instances when it is significant, it is often positive rather than negative. In column 6 of table 9, for instance, the tertiary school enrollment variable generates a strong, positive coefficient, while five of the twelve coefficients of the Doing Business indicators are insignificant, four are actually positive, and only three are negative, as predicted. In column 8 , health care expenditure and GDP per capita are positively associated with efficiency, while only one of the Doing Business indicators is significant and positive.
Results based on Heritage Foundation indicators (not reported in a tabular form here) are similar. The results in tables 8 and 9 suggest that human capital and other effects associated with greater tertiary school enrollment and health care expenditures may be more systematically conducive to firm efficiency than lighter business environment constraints.

\section{Conclusion}

It has become fashionable in recent years to argue that the business environment plays a major role in determining the overall strength of a given economy, primarily through its impact on the performance of firms. "Bad" business environments-commonly characterized as those in which, for example, corruption and regulation are high and there is pervasive uncertainty with respect to taxation, business licensing, or even macroeconomic policy-are widely believed to cause poor economic performance. The evi- 
dence for such conclusions has been drawn from a variety of sources, including cross-country estimations of growth but also, increasingly, from firm-level surveys that have gathered subjective information on perceived constraints to activity emanating from the business environment. However, while the general thrust of the argument-that the business environment is an important determinant of economic performance-carries considerable intuitive appeal, the importance of establishing the hypothesized relationship through careful analysis of data cannot be emphasized enough. A similar reasoning applies to the relatively broadly accepted notion that private ownership of basically any kind generates superior performance to state ownership of firms. Indeed, a certain amount of recent research in this area using aggregate and firm-level survey evidence may be misleading through its reliance on relatively simple econometric implementation that may suffer from biases due to omitted variables, measurement error, and endogeneity.

In this paper, we have addressed the challenge by using firm-level information (the BEEPS and, to a lesser extent, the AMADEUS data set), as well as country-level Doing Business and Heritage Foundation indicators, to analyze the performance effects of firm's ownership, competition, export orientation, and the business (institutional) environment. To that end, we have employed a variety of approaches, including instrumental variables and using average values of constraints reported by other firms with similar characteristics. We find evidence that ownership and competition exert an impact on performance, but the results differ from much of the earlier literature in that foreign ownership of firms has a positive effect on performance but domestic private ownership does not. Export orientation of the firm is found to have a positive effect on performance in simple specifications, but the effect disappears once firm ownership is taken into account (foreign firms tend to be the principal efficient exporters). When we examine the impact of perceived business environment constraints, we find that few retain explanatory power, in either IV or OLS specification, once they are entered simultaneously rather than one at a time, or once country, year, and sector fixed effects are introduced. Indeed, country fixed effects largely absorb the explanatory power of the constraints in all specifications. In neither the level equations nor the initial value rates of change regressions can we identify any strong and robust effects of these variables. The lack of an effect is found in both the BEEPS and AMADEUS firm-level data and in firm-level (BEEPS) and country level (Doing Business and Heritage) indicators of business environment. It is thus not brought about by a peculiarity of a given data set.

The lack of a detectable effect of the reported severity of various constraints in the business environment could reflect the fact that (a) firms can get around these constraints at a relatively low cost and the effect is hence not detectable in the data (for example, the firms may pay a bribe to obtain a license, but the cost of the bribe is small); or (b) managers who face severe constraints compensate for the presence of these constraints and report lower severity than is actually the case (for example, firms that need more external financing may "pre-save" from retained earnings and consequently report a lower severity of the financing constraint than is in fact the case). Since we observe significant variation in reported constraints across firms, the latter phenomenon of compensating for constraints may reduce the observed effect of constraints but is unlikely to eliminate it altogether.

In order to see if the overall results are brought about by some peculiarity of our business environment data, we have also replicated the level equations using the country-level indicators of the business environment provided by the Heritage Foundation and the World Bank. We again do not detect a systematic relationship between constraints and performance.

We show that country effects, reflecting differences in the business environment but also many other factors, matter for firm performance but that differences in the business environment constraints observed across firms within countries do not. Moreover, the limited firm- and country-level variations in the business environment over time do not appear to affect performance either. A closer inspection of the country fixed effects reveals that they are to some extent correlated with the expected differences in corporate performance but are also likely to be capturing other sources of cross-country heterogeneity. Given that much donor funding has been conditioned on improvements in the business environment, our findings raise the question of whether other development policies that use bilateral or multilateral funding yield similarly insignificant effects. We take a step toward answering this question by exploring whether indicators such as country-wide tertiary school enrollment or expenditures on health care-proxies for policies aimed at improvements in human capital-have a significant effect on firm performance relative to the business environment constraints. We find that in some regressions, tertiary school enrollment and health care expenditure per GDP have stronger (positive) effects on firm performance than Doing Business or Heritage Foundation indicators of business environment. Including GDP per capita has a positive effect on performance in all regressions and suggests that the country fixed effects that eliminate the effect of the individual business constraints in our earlier regressions are well approximated by intercountry differences in GDP per capita.

Overall, our analysis brings into question the conventional wisdom in this important area. It suggests that analysts' ability to identify the effect of business environment on performance, and possibly the effect itself, have been more limited than has been widely assumed to date. It indicates that it is important to control for country effects, realizing that they capture many features of heterogeneity, rather than excluding them or attributing the cross-country 
heterogeneity to just a single factor such as the business (institutional) environment. Finally, the evidence suggests that policymakers ought not to rely on simple indicators of business environment and that further discussion and research are needed about the relative merits of alternative development policies and funding priorities.

\section{REFERENCES}

Aghion, P., Richard Blundell, Nick Bloom, Rachel Griffith, and Peter Howitt, "Competition and Innovation: An Inverted U Relationship," Quarterly Journal of Economics 120 (2005), 701-728.

Aghion, P., R. Burgess, S. Redding, and F. Zilibotti, "The Unequal Effects of Liberalization: Evidence from Dismantling the License Raj in India," mimeograph, Harvard University (2006).

Ayyagari, Meghana, and Asli Demirguc-Kunt, "How Important Are Financing Constraints? The Role of Finance in the Business Environment," World Bank Policy Research working paper no. 3820, revised (January 2008).

Beck, T., A. Demirguc-Kunt, and V. Maksimovic, "Financial and Legal Constraints to Growth: Does Firm Size Matter?" Journal of Finance 60 (2005), 137-177.

Botero, J, S. Djankov, R. La Porta, F. Lopez de Silanes, and A. Shleifer, "The Regulation of Labor," Quarterly Journal of Economics 119 (2004), 1339-1382.

Carlin, W., "Empirical Analysis of Corporate Governance in Transition," in E. Rosenbaum, F. Bönker, and H.-J. Wagener (Eds.), Privatisation, Corporate Governance and the Emergence of Markets (Basingstoke/London: Macmillan, 2000).

Carlin, W., S. Fries, M. Schaffer, and P. Seabright, "Competition, Restructuring and Firm Performance: Evidence of an Inverted-U Relationship from a Cross Country Survey of Firms in Transition Economies," CEPR discussion paper no. 2840 (2001).

"A Minimum of Rivalry: Evidence from Transition Economies on the Importance of Competition for Innovation and Growth," B.E. Journal of Economic Analysis \& Policy 3:1 (2004), article 17

Carlin, W., M. Schaffer, and P. Seabright, "Where Are the Real Bottlenecks? A Lagrangian Approach to Identifying Constraints on Growth from Subjective Survey Data," CEPR discussion paper no. 5719 (2006).

Claessens, S., and S. Djankov, "Ownership Concentration and Corporate Performance in the Czech Republic," Journal of Comparative Economics 27 (1999), 498-513.

Djankov, S., and P. Murrell, "Enterprise Restructuring in Transition: A Quantitative Survey," World Bank working paper (2002).

Dollar, D., M. Hallward-Driemeier, and T. Mengistae, "Investment Climate and International Integration," World Bank working paper (2005).

Durnev, A., and H. Kim, "To Steal or Not to Steal: Firm Attributes, Legal Environment, and Valuation," Journal of Finance 60 (2005), 1461-1493.

Durnev, A., K. Li, R. Morck, and B. Yeung, "Capital Markets and Capital Allocation: Implications for Economies in Transition," Economics of Transition 12 (2004), 593-634.

Estrin, S., J. Hanousek, E. Kocenda, and J. Svejnar, "Effects of Privatization and Ownership in Transition Economies," Journal of Economic Literature 47 (2009), 699-728.

EBRD, Transition Report (London: EBRD, 1995). Transition Report (London: EBRD, 1999).

Frydman, R., C. Gray, M. Hessel, and A. Rapaczynski, "When Does Privatization Work? The Impact of Private Ownership on Corporate
Performance in the Transition Economies," Quarterly Journal of Economics 114 (1999), 1153-1191.

Gupta, N., J. C. Ham, and J. Svejnar, "Priorities and Sequencing in Privatization: Evidence from Czech Firm Panel Data," European Economic Review 52 (2008), 183-208.

Hallward-Driemeier, M., S. J. Wallstein and L. C. Xu, "Ownership, Investment Climate and Firm Performance," Economics of Transition 14 (2006), 629-647.

Hanousek, J., E. Kocenda, and J. Svejnar, "Origin and Concentration: Corporate Ownership, Control and Performance," Economics of Transition 15:1 (2007).

Hausmann, R., D. Rodrik, and A. Velasco, "Growth Diagnostics," mimeograph: Harvard University, Kennedy School (2004).

Heritage Foundation, Index of Economic Freedom (Washington, DC: Heritage Foundation, 2001).

Index of Economic Freedom (Washington, DC: Heritage Foundation, 2004).

Johnson, S., J. McMillan, and C. Woodruff, "Property Rights and Finance," American Economic Review 92:5 (2002a).

"Courts and Relational Contracts," Journal of Law, Economics and Organisation 18 (2002b), 221-277.

Kaufmann, D. "Governance Crossroads," in Global Competitiveness Report, 2002-2003 (New York: Oxford University Press, 2002).

Kaufmann, D., A. Kraay, and P. Zoido-Lobaton, "Governance Matters," World Bank Policy Research working paper no. 2196 (1999).

Klapper, L., and I. Love, "Corporate Governance, Investor Protection and Performance in Emerging Markets," Journal of Corporate Finance 10 (2004), 703-728.

Levine, S., and S. Zervos, "Stock Markets, Banks and Growth," American Economic Review 88 (1998), 537-558.

Marschak, J., and W. H. Andrews, "Random Simultaneous Equations and the Theory of Production," Econometrica 12 (1944), 143205.

Micco, Alejandro, and Carmen Pages, "The Economic Effects of Employment Protection: Evidence from International IndustryLevel Data," IZA discussion paper no. 2433 (2006).

Nickell, S., "Competition and Corporate Performance," Journal of Political Economy 105 (1999), 724-746.

Pissarides, F., M. Singer, and J. Svejnar, "Objectives and Constraints of Entrepreneurs: Evidence from Small and Medium Size Enterprises in Russia and Bulgaria," Journal of Comparative Economics 31 (2003), 503-531.

Rajan, R., and L. Zingales, "Financial Development and Growth," American Economic Review 88 (1998), 559-586.

Sabirianova, K., J. Svejnar, \& K. Terrell, "Distance to the Efficiency Frontier and Foreign Direct Investment Spillover," Journal of the European Economic Association Papers and Proceedings 3 (2005a) 576-586.

"Foreign Investment, Corporate Ownership and Development: Are Firms in Emerging Markets Catching Up to the World Standard?" IZA discussion paper no. 1457 (2005b).

Schmidt, P., "Estimation of a Fixed-Effect Cobb-Douglas System Using Panel Data," Journal of Econometrics 37 (1988), 361-380.

Tybout, J., "Plant and Firm-Level Evidence on the 'New' Trade Theories," in E. Kwan Choi and J. Harrigan (Eds.), Handbook of International Trade (Oxford: Basil Blackwell, 2003).

World Bank, Business Environment and Enterprise Performance Survey (Washington, DC: World Bank, 2002).

Business Environment and Enterprise Performance Survey (Washington, DC: World Bank, 2005).

Doing Business (Washington, DC: World Bank, 2003). Doing Business (Washington, DC: World Bank, 2006).

World Economic Forum, Global Competitiveness Report (Cologny/ Geneva, Switzerland: World Economic Forum, 2005). 


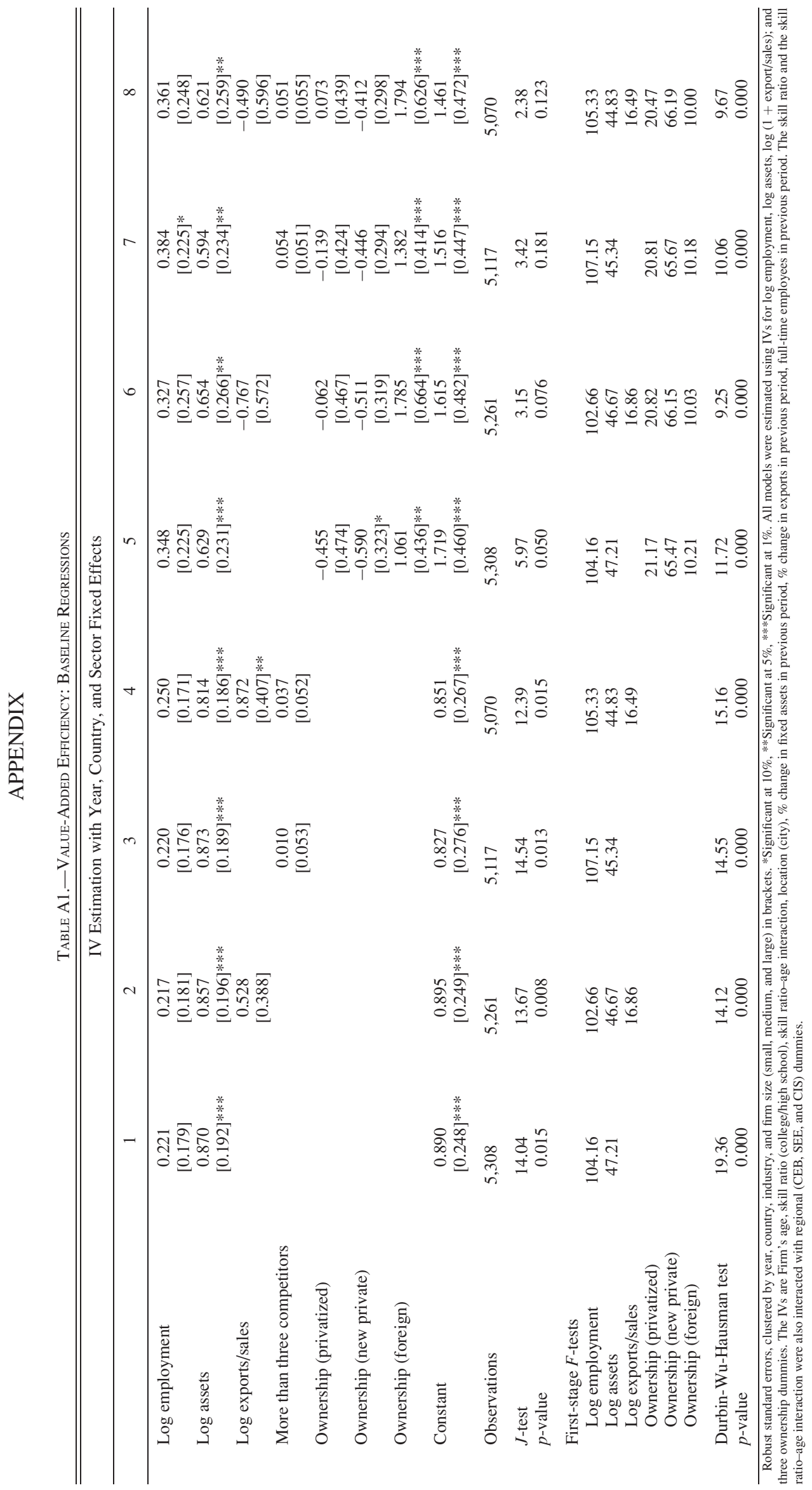




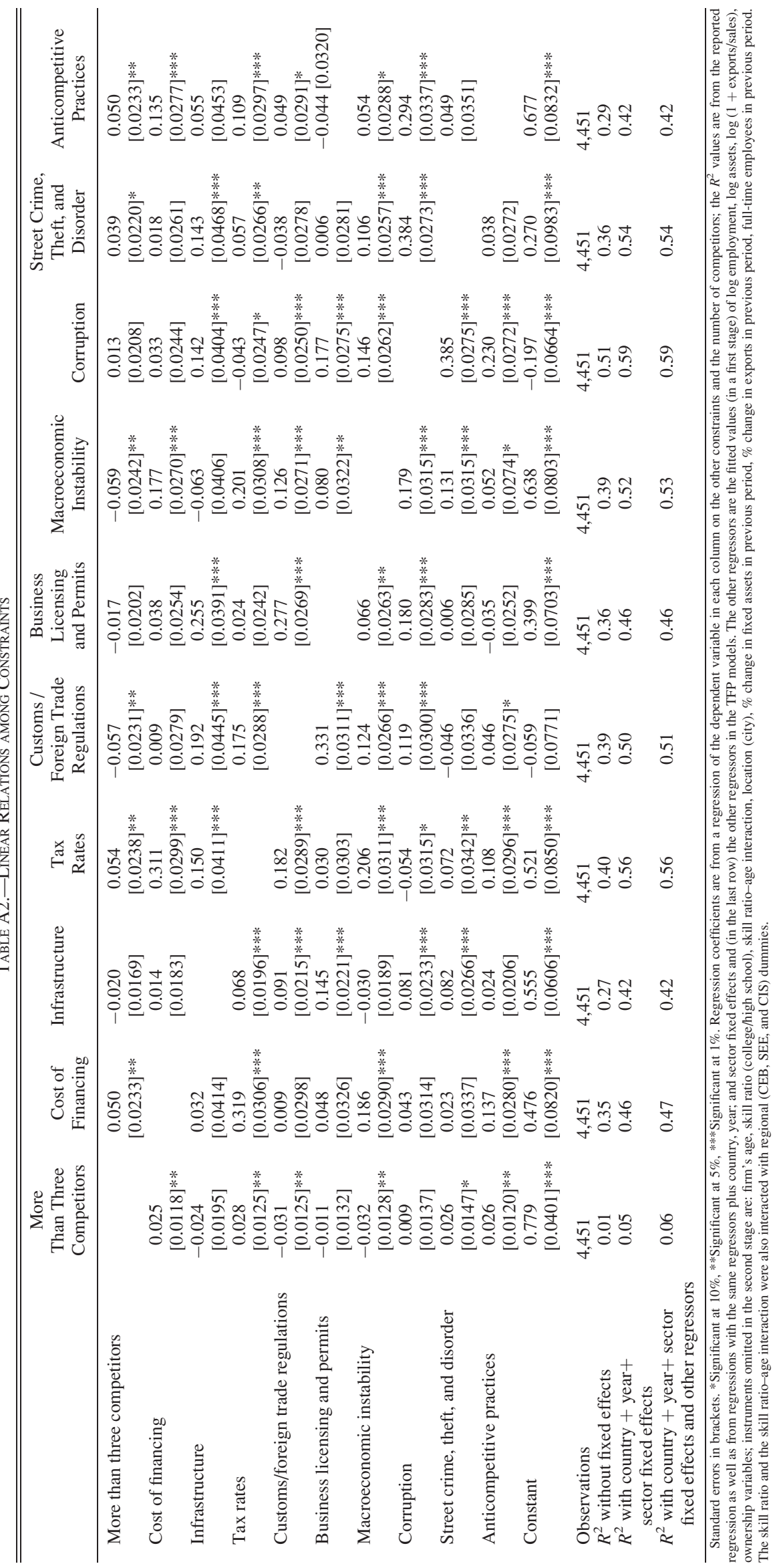




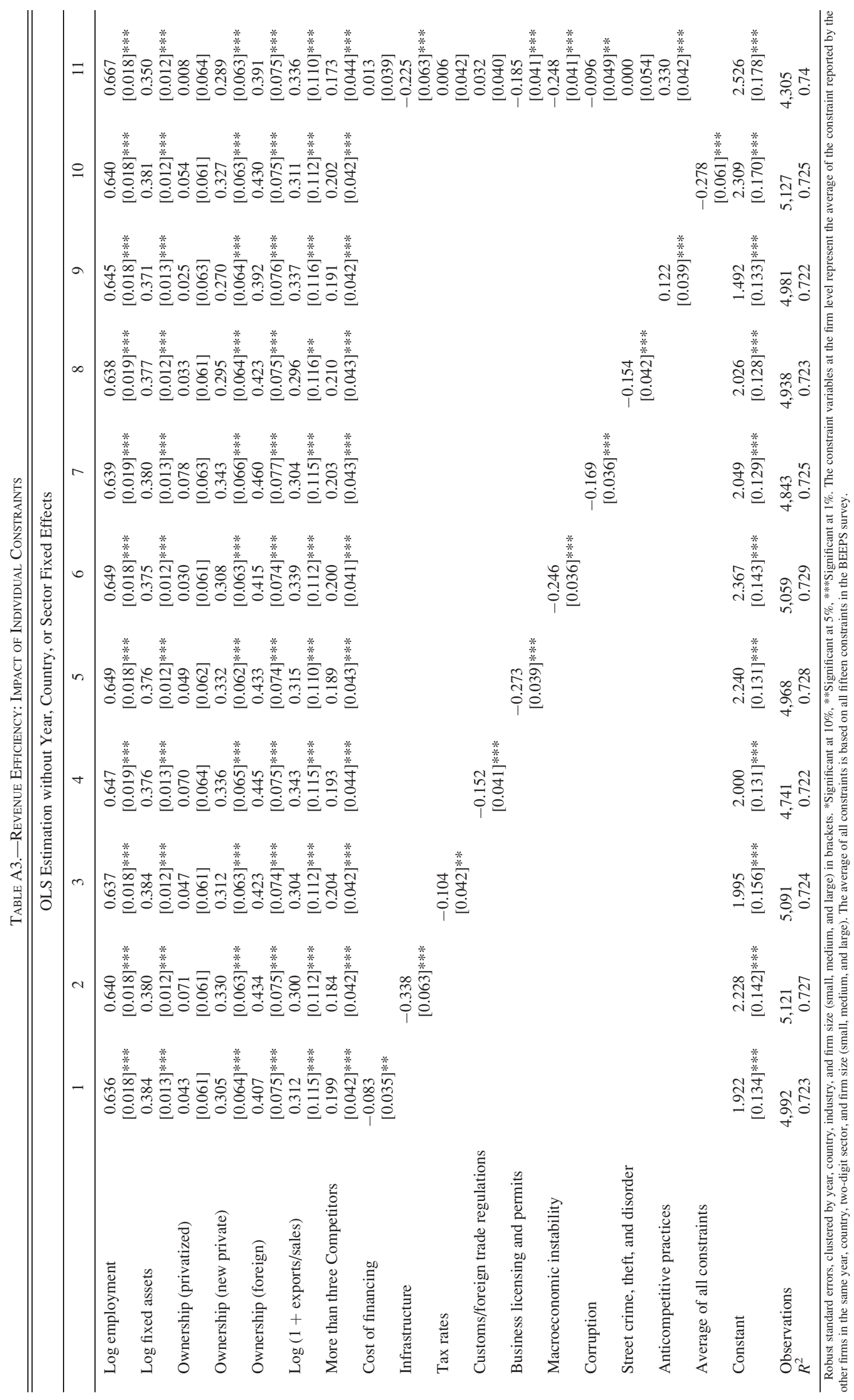




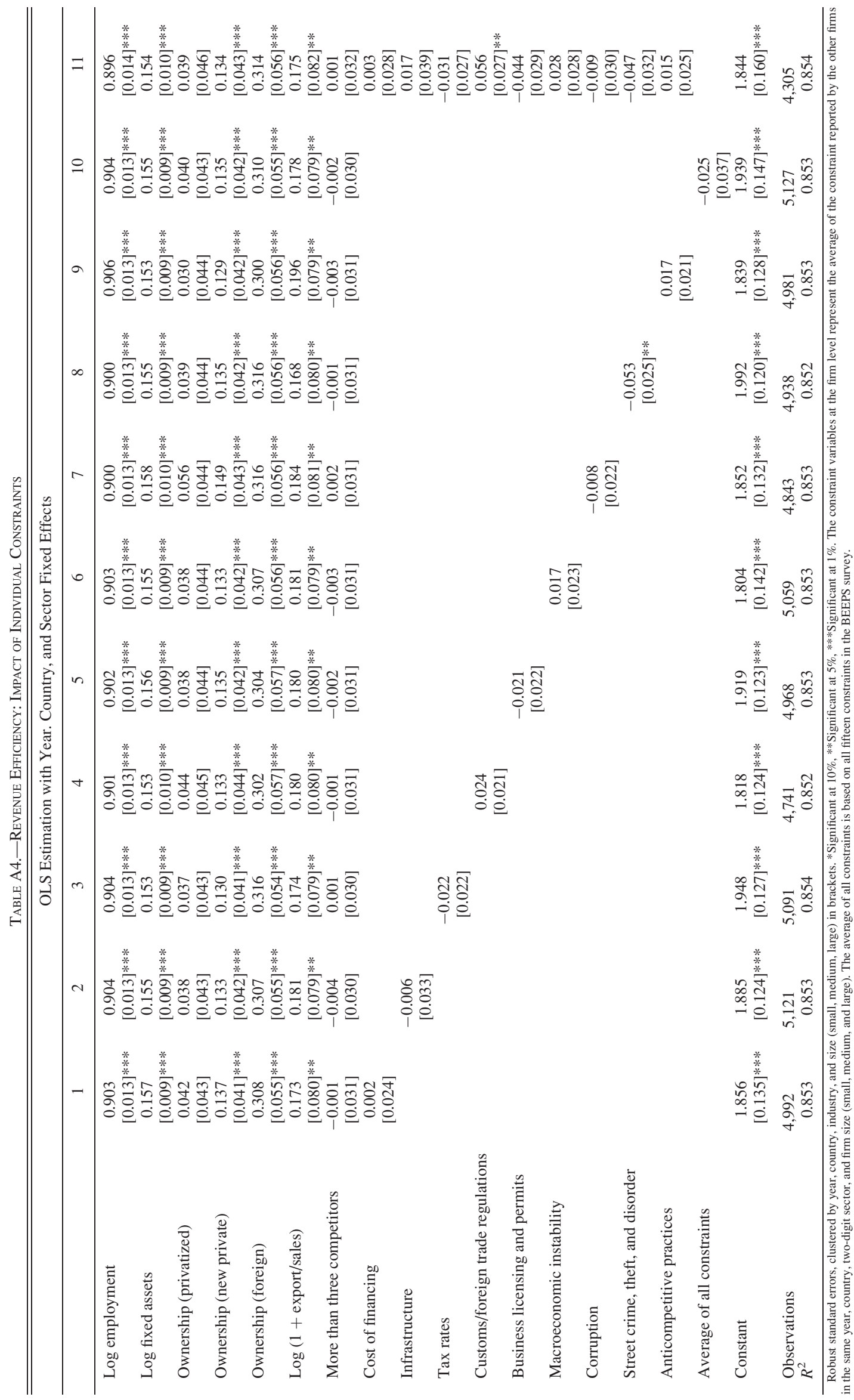




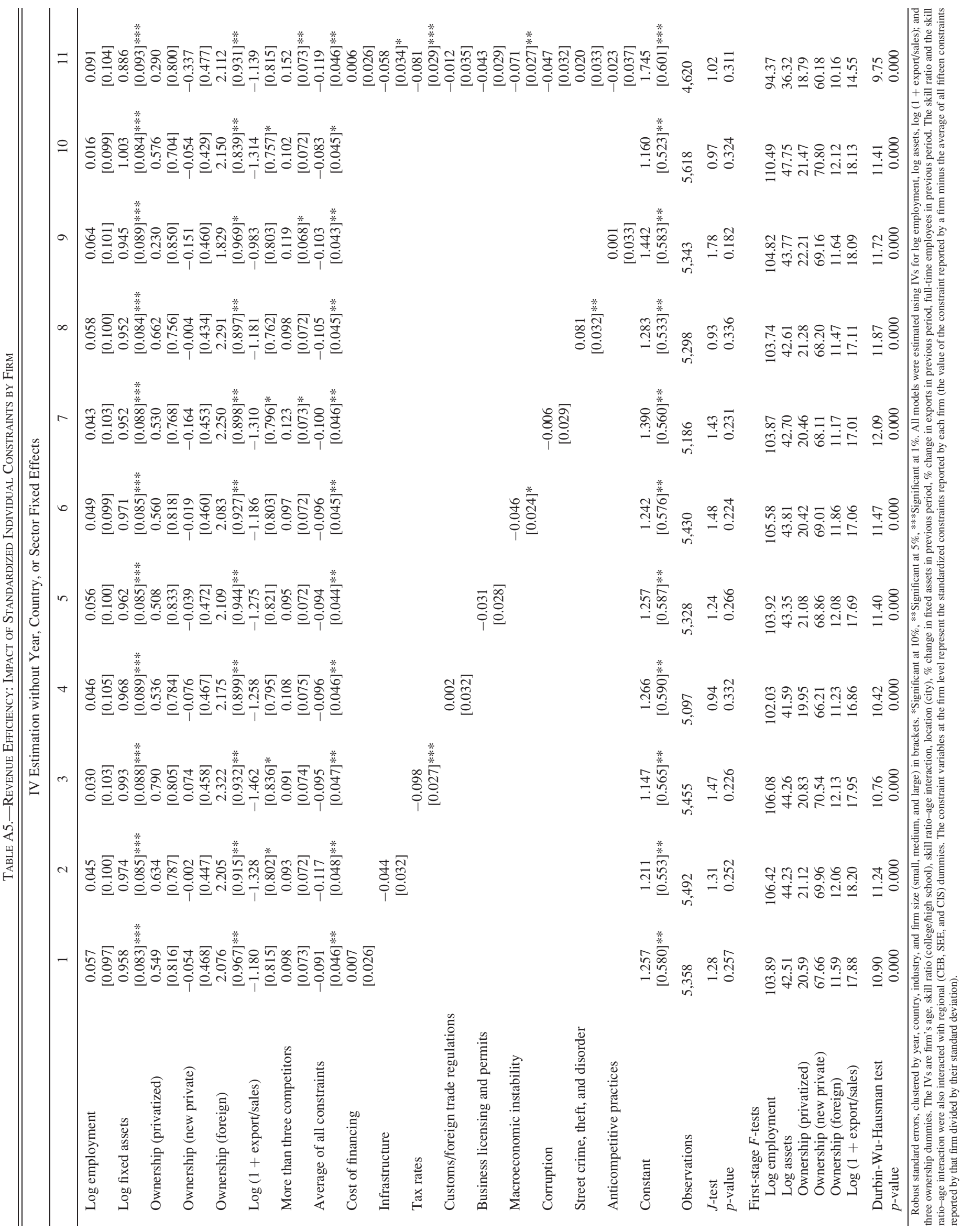




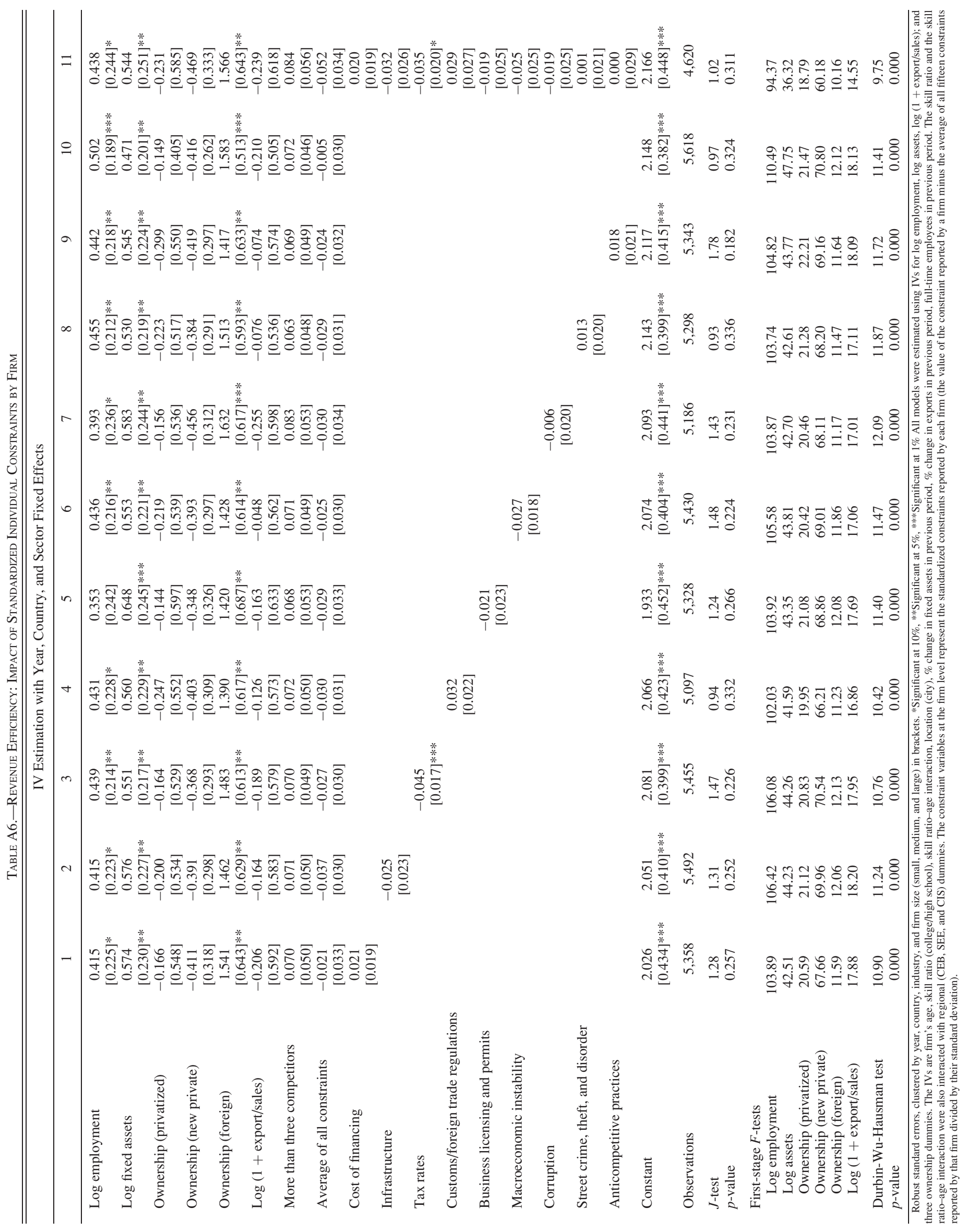




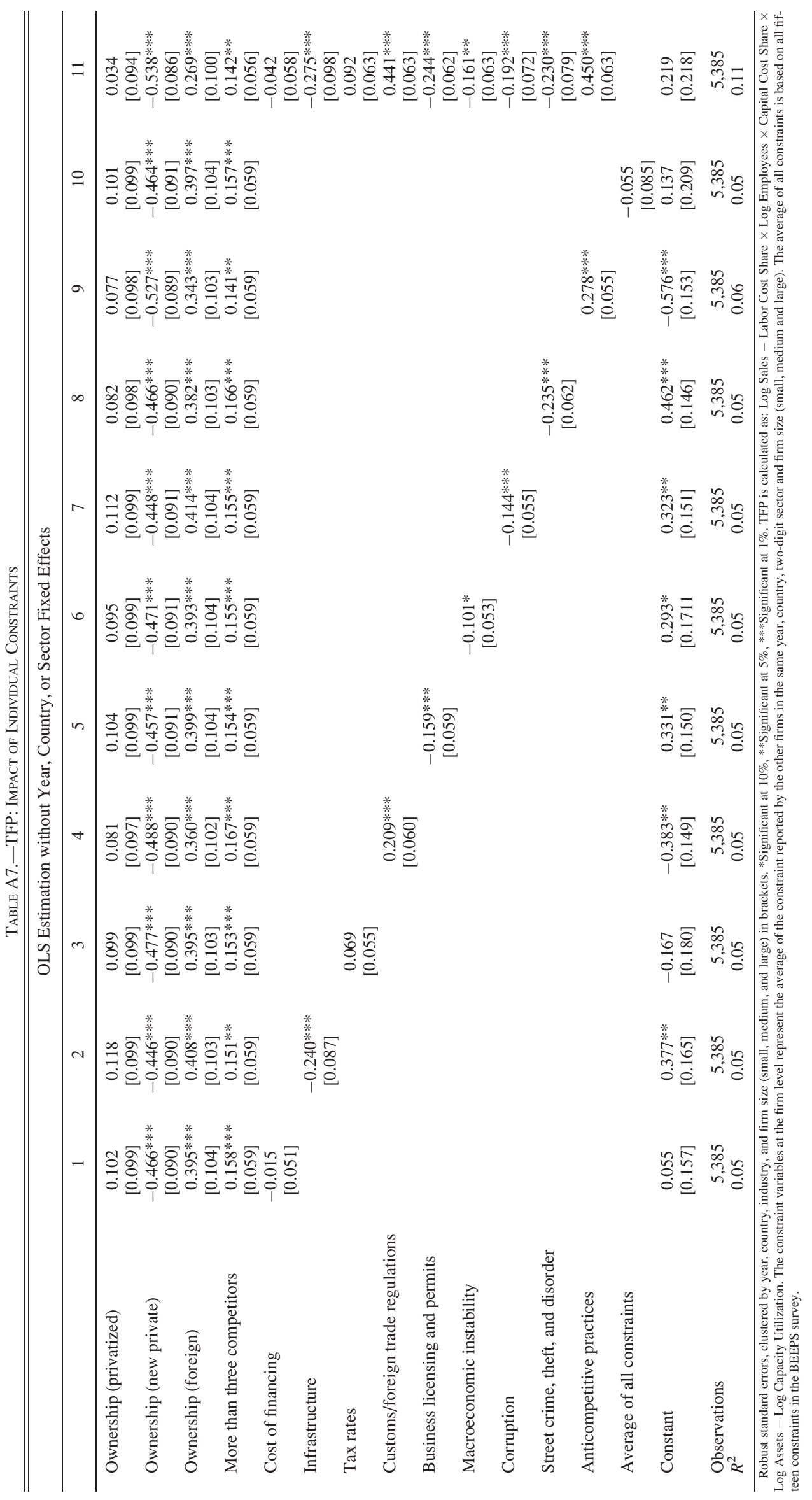


Table A8.-Revenue Efficiency: Baseline Regressions on Panel Data

\begin{tabular}{|c|c|c|c|c|c|c|c|c|}
\hline \multicolumn{9}{|c|}{ IV Estimation with Year, Country, and Sector Fixed Effects } \\
\hline & 1 & 2 & 3 & 4 & 5 & 6 & 7 & 8 \\
\hline Log employment & $\begin{array}{c}0.389 * * \\
{[0.169]}\end{array}$ & $\begin{array}{l}0.457 * * * \\
{[0.171]}\end{array}$ & $\begin{array}{c}0.402 * * \\
{[0.174]}\end{array}$ & $\begin{array}{c}0.489 * * * \\
{[0.173]}\end{array}$ & $\begin{array}{l}0.755^{* * *} * \\
{[0.189]}\end{array}$ & $\begin{array}{l}0.731 \text { *** } \\
{[0.193]}\end{array}$ & $\begin{array}{l}0.735^{* * *} * \\
{[0.193]}\end{array}$ & $\begin{array}{l}0.710 * * * \\
{[0.204]}\end{array}$ \\
\hline Log assets & $\begin{array}{l}0.709 * * * \\
{[0.187]}\end{array}$ & $\begin{array}{l}0.610 * * * \\
{[0.200]}\end{array}$ & $\begin{array}{l}0.702 * * * \\
{[0.192]}\end{array}$ & $\begin{array}{l}0.578 * * * \\
{[0.202]}\end{array}$ & $\begin{array}{c}0.289 \\
{[0.225]}\end{array}$ & $\begin{array}{c}0.316 \\
{[0.244]}\end{array}$ & $\begin{array}{c}0.321 \\
{[0.229]}\end{array}$ & $\begin{array}{c}0.349 \\
{[0.255]}\end{array}$ \\
\hline Log $(1+$ exports/sales $)$ & & $\begin{array}{c}0.825 \\
{[0.593]}\end{array}$ & & $\begin{array}{c}1.021 \\
{[0.670]}\end{array}$ & & $\begin{array}{l}-0.005 \\
{[0.683]}\end{array}$ & & $\begin{array}{l}-0.023 \\
{[0.775]}\end{array}$ \\
\hline More than three competitors & & & $\begin{array}{r}-0.004 \\
{[0.081]}\end{array}$ & $\begin{array}{c}0.007 \\
{[0.074]}\end{array}$ & & & $\begin{array}{l}-0.069 \\
{[0.073]}\end{array}$ & $\begin{array}{l}-0.067 \\
{[0.075]}\end{array}$ \\
\hline Ownership (privatized) & & & & & $\begin{array}{c}0.235 \\
{[0.427]}\end{array}$ & $\begin{array}{c}0.208 \\
{[0.445]}\end{array}$ & $\begin{array}{c}0.401 \\
{[0.422]}\end{array}$ & $\begin{array}{c}0.388 \\
{[0.455]}\end{array}$ \\
\hline Ownership (new private) & & & & & $\begin{array}{c}0.089 \\
{[0.317]}\end{array}$ & $\begin{array}{c}0.053 \\
{[0.349]}\end{array}$ & $\begin{array}{c}0.215 \\
{[0.314]}\end{array}$ & $\begin{array}{c}0.180 \\
{[0.352]}\end{array}$ \\
\hline Ownership (foreign) & & & & & $\begin{array}{l}1.904 * * * \\
{[0.473]}\end{array}$ & $\begin{array}{l}1.942 * * * \\
{[0.452]}\end{array}$ & $\begin{array}{l}1.835^{* * * *} \\
{[0.447]}\end{array}$ & $\begin{array}{l}1.878 * * * \\
{[0.414]}\end{array}$ \\
\hline Constant & $\begin{array}{l}1.343 * * * \\
{[0.330]}\end{array}$ & $\begin{array}{l}1.446 * * * \\
{[0.336]}\end{array}$ & $\begin{array}{l}1.292 * * * \\
{[0.373]}\end{array}$ & $\begin{array}{l}1.418 * * * \\
{[0.367]}\end{array}$ & $\begin{array}{l}1.471^{* *} \\
{[0.592]}\end{array}$ & $\begin{array}{l}1.459^{* *} \\
{[0.680]}\end{array}$ & $\begin{array}{l}1.367 * * \\
{[0.609]}\end{array}$ & $\begin{array}{r}1.348 * \\
{[0.711]}\end{array}$ \\
\hline Observations & 1,372 & 1,355 & 1,322 & 1,305 & 1,372 & 1,355 & 1,322 & 1,305 \\
\hline $\begin{array}{l}J \text {-test } \\
p \text {-value }\end{array}$ & $\begin{array}{r}16.75 \\
0.005\end{array}$ & $\begin{array}{c}15.34 \\
0.004\end{array}$ & $\begin{array}{r}16.94 \\
0.005\end{array}$ & $\begin{array}{r}14.76 \\
0.005\end{array}$ & $\begin{array}{l}6.55 \\
0.162\end{array}$ & $\begin{array}{l}5.01 \\
0.025\end{array}$ & $\begin{array}{l}6.70 \\
0.035\end{array}$ & $\begin{array}{l}4.98 \\
0.418\end{array}$ \\
\hline $\begin{array}{l}\text { First-stage } F \text {-tests } \\
\text { Log employment } \\
\text { Log assets } \\
\text { Log (1+ exports/sales) } \\
\text { Ownership (privatized) } \\
\text { Ownership (new private) } \\
\text { Ownership (foreign) }\end{array}$ & $\begin{array}{l}42.19 \\
17.89\end{array}$ & $\begin{array}{r}41.40 \\
18.04 \\
5.86\end{array}$ & $\begin{array}{l}50.78 \\
19.05\end{array}$ & $\begin{array}{r}49.46 \\
19.32 \\
5.22\end{array}$ & $\begin{array}{r}42.19 \\
17.89 \\
\\
5.94 \\
22.00 \\
5.75\end{array}$ & $\begin{array}{r}41.40 \\
18.04 \\
5.86 \\
5.77 \\
23.12 \\
5.81\end{array}$ & $\begin{array}{r}50.78 \\
19.05 \\
\\
6.73 \\
25.48 \\
5.91\end{array}$ & $\begin{array}{r}49.46 \\
19.32 \\
5.22 \\
6.62 \\
26.85 \\
5.91\end{array}$ \\
\hline $\begin{array}{l}\text { Durbin-Wu-Hausman test } \\
p \text {-value }\end{array}$ & $\begin{array}{l}8.16 \\
0.000\end{array}$ & $\begin{array}{l}5.91 \\
0.001\end{array}$ & $\begin{array}{l}6.67 \\
0.000\end{array}$ & $\begin{array}{l}6.35 \\
0.000\end{array}$ & $\begin{array}{l}6.96 \\
0.000\end{array}$ & $\begin{array}{l}5.75 \\
0.000\end{array}$ & $\begin{array}{l}6.06 \\
0.000\end{array}$ & $\begin{array}{l}6.13 \\
0.000\end{array}$ \\
\hline
\end{tabular}

Robust standard errors, clustered by year, country, industry, and firm size (small, medium, and large) in brackets. *Significant at $10 \%$, **Significant at $5 \%, * * *$ Significant at $1 \%$. All models were estimated using IVs for log employment, log assets, log (1 + export/sales), and three ownership dummies. The IVs are firm's age, skill ratio (college/high school), skill ratio-age interaction, location (city), \% change in fixed assets in previous period, \% change in exports in previous period, full-time employees in previous period. The skill ratio and the skill ratio-age interaction were also interacted with regional (CEB, SEE, and CIS) dummies. 